\title{
Mineral chemistry of In-bearing minerals in the Santa Fe mining district, Bolivia
}

\author{
*Abigail Jiménez-Franco'1, Pura Alfonso ${ }^{1}$, Carles Canet ${ }^{2}$, Juan Elvys Trujillo \\ ${ }^{I}$ Deptament d'Enginyeria Minera, Industrial i TIC, Universitat Politécnica de Catalunya, Av. de les Bases de Manresa 61-73, 08242 \\ Manresa, Barcelona, Spain. \\ abigail@emrn.upc.edu; maria.pura.alfonso@upc.edu \\ 2 Centro de Ciencias de la Atmósfera e Instituto de Geofísica, Universidad Nacional Autónoma de México, Ciudad Universitaria, Coyoacán \\ 04510, Ciudad de México, México. \\ ccanet@atmosfera.unam.mx \\ 3 Facultad Nacional de Ingeniería, Universidad Técnica de Oruro, Pagador No. 5777, Oruro, Bolivia. \\ jelvyst20@gmail.com \\ *Corresponding author: abigail@emrn.upc.edu
}

\begin{abstract}
The Santa Fe mining district is located in the Central Andean tin belt of Bolivia and contains several Sn$\mathrm{Zn}-\mathrm{Pb}-\mathrm{Ag}$ deposits. From the economic point of view, the most important deposits of the district are Japo, Santa Fe and Morococala. Beyond the traditional metal commodities, the Central Andean Tin Belt could become an exploration target for indium, owing to the potential of the ore-bearing paragenesis with high concentrations of this technology-critical element. In the Santa Fe mining district, the ore occurs as two main types: (a) Sn-rich cassiterite-quartz veins, and (b) $\mathrm{Zn}-\mathrm{Pb}-\mathrm{Ag}$ veins with sphalerite, galena and stannite mineral phases. The In content in igneous rocks is between 1.5 and $2.5 \mathrm{ppm}$, whereas in the ore concentrate it attains up to $200 \mathrm{ppm}$. The $1,000 \times \mathrm{In} / \mathrm{Zn}$ ratio in concentrate ranges from 25 up to 4,000. Exceptionally high In values were found in sakuraiite from Morococala deposit (2.03 wt\%). Sakuraiite in this deposit shows evidences for a link between stannite and kësterite trend of solid solutions. There is a noteworthy exploration potential for strategic metals in this district and even in similar deposits elsewhere in the Central Andean tin belt.
\end{abstract}

Keywords: Indium, Tin, Greisen, Stannite, Sakuraiite, Sulfosalts.

RESUMEN. Química de fases minerales portadoras de In en el distrito minero Santa Fe, Bolivia. El distrito minero Santa Fe se encuentra ubicado en la Faja Estannífera de la cordillera Central Andina de Bolivia, que aloja diversos depósitos de $\mathrm{Sn}-\mathrm{Zn}-\mathrm{Pb}-\mathrm{Ag}$. Desde el punto de vista económico, los depósitos más importantes en este distrito son los de Japo, Santa Fe y Morococala. Más allá de los productos metálicos tradicionales, la Faja Estannífera podría convertirse en un blanco de exploración para elementos como el indio, por el potencial de su paragénesis mineral con altas concentraciones de este elemento, crítico para el desarrollo de tecnología. Los yacimientos minerales del distrito de Santa Fe se presentan en dos tipos principales: (a) depósitos ricos en $\mathrm{Sn}$, constituidos por vetas de cuarzo con casiterita, y (b) depósitos diseminados de $\mathrm{Zn}-\mathrm{Pb}-\mathrm{Ag}$, con esfalerita, galena y estannita. El contenido de In en las rocas ígneas del distrito, varía entre 1,5 y 2,5 ppm, mientras que en el concentrado de los minerales de mena alcanza hasta 200 ppm de In. Asimismo, la razón $1.000 \times \mathrm{In} / \mathrm{Zn}$ en concentrados de mineral oscila entre 25 y 4.000 . Fases de sakuraíta del yacimiento de Morococala contienen valores excepcionales de In (hasta $2.03 \%$ en peso). La sakuraiíta en el distrito minero de Santa Fe muestra evidencia de ser el vínculo mineralógico entre la tendencia general de las soluciones sólidas de estannita y kësterita. Existe un potencial de exploración obvio para metales estratégicos en este distrito e incluso en depósitos similares en otras zonas de la Faja Estannífera en la cordillera Central Andina. 


\section{Introduction}

The Central Andean tin belt province of Bolivia hosts many world-class deposits as Cerro Rico, Llallagua and San José (Mlynarczyk and WilliamJones, 2005). It extends in NW-SE direction for approximately $900 \mathrm{~km}$ trough the Eastern Cordillera of Bolivia. The Santa Fe mining district (SFD) is located in this province and contains several Sn-Zn$\mathrm{Pb}$-Ag deposits and occurrences; among them, Japo, Santa Fe and Morococala are the most important from the economic point of view (Fig. 1). Santa Fe and Morococala mines are separated $\sim 2 \mathrm{~km}$ each other, whereas Japo is located $\sim 10 \mathrm{~km}$ farther, towards NW from them. The first mining activity in the SFD started in Japo at the beginning of the $20^{\text {th }}$ century. Later, in the 20's, Mr. Simón Iturri Patiño became the owner of all the mines in the SFD as he was in those days of most deposits in Bolivia. From 1950 the Bolivian government managed the SFD; historically, those times were the most productive.

Sugaki et al., (1981) reported grade $1.15 \mathrm{wt} \%$ $\mathrm{Sn}$ in Japo, $0.68 \mathrm{wt} \% \mathrm{Sn}$ in Santa Fe and $0.59 \mathrm{wt} \%$ $\mathrm{Sn}$ in Morococala. In the 80's many deposits in Bolivia started to be mined by artisanal miners grouped in cooperatives. Nowadays, Japo, Santa Fe and Morococala deposits are exploited by three different artisanal cooperatives.

Despite the economic value and geopolitical importance of mineral resources in the Central Andes, most deposits there have been poorly studied, especially from the mineralogical and metallogenic points of view. Based on changes in the character of the mineral deposits, were described the main metallogenic provinces in the Altiplano, dividing the Central Andean tin belt in Northern and Southern

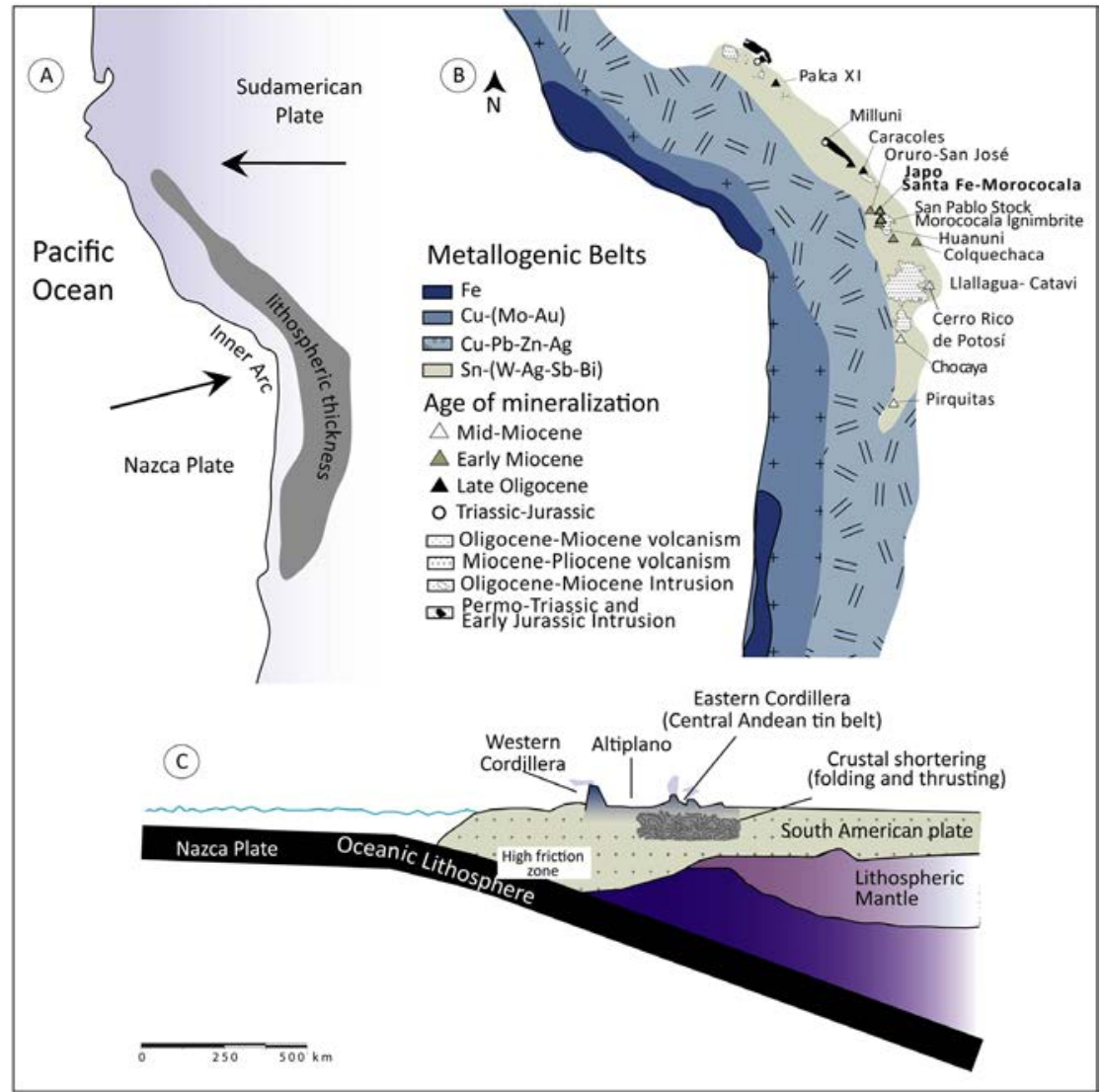

FIG. 1. Principal metallogenic belts and ore deposits of the Central Andean Tin belt (after Mlynarczyk and William-Jones, 2005). A. Plate tectonics, volcanism and lithospheric thickness; B. Relevant ore deposit with time in the Central Andean tin belt; C. Schematic cross-section of the Andean continental margin, showing the relationships. 
parts; also different metallogenic ages to each of them were defined for the first time (Ahlfeld, 1967). The northern part contain $\mathrm{Au}, \mathrm{W}, \mathrm{Sb}, \mathrm{Sn}, \mathrm{Bi}, \mathrm{Zn}$, $\mathrm{Pb}$ deposits. Meanwhile, in the Southern part Ag is also present. The first publication from the SFD ore deposits includes a mineralogical and fluid inclusion characterization of many $\mathrm{Sn}$ and $\mathrm{W}$ deposits along the eastern Bolivian Andean Belt (Kelly and Turneaure, 1970). This study suggests that all the deposits in the Central Andean tin belt are due to a single but temporary extensive event of mineralization. Sugaki et al. (1988) contributed with new information from fluid inclusions in many ore deposits. They proposed that changes of temperature and salinity correspond with a zonal arrangement of minerals observed in many polymetallic deposits in Bolivia. Meanwhile, Sillitoe et al. (1975) proposed that most Sn deposits in Bolivia belong to the porphyry tin type; they included the San Pablo stock and the Japo mine as part of their study. Sugaki et al. (1981) carried out a geological study on hydrothermal deposits in the Oruro department. These authors proposed a genetic link between the Santa Fe, Morococala and Japo deposits. They described a Sn-Zn-Pb-Ag metallogenic association and reported the largest geological structures of the area (Sugaki et al., 1981; Sugaki et al., 2003). More recently, several studies have been done in the Central Andean tin belt focusing on the potential of its ore associations as a source of indium (Ishihara et al., 2011; Murakami and Ishihara, 2013).

Indium is considered as a strategic metal for the European Union because of its technological applications and the risk of supply disruption (Chapman et al., 2013). Due to the increased demand for indium in a number of high-technology applications, this element has attracted considerable attention in recent years (Cook et al., 2011a). Additionally, indium-tin oxide (ITO) is used as a thin-film coating on flatscreens (LCDs). In 2014, global ITO production capacity was about 2,090 t/yr (Tolcin, 2016). On the other hand, the USGS (Tolcin, 2016) reported that ITO is leading the use of this metal, accounting for $55 \%$ to $85 \%$ of the global consumption, and reflecting the strong relationship between indium and tin as commodities.

In this work is presented the paragenetic and mineral chemistry data of three deposits of the SFD -Japo, Santa Fe and Morococala-, with the goal of defining a comprehensive metallogenic model for the district. Additionally, the ore assemblages, especially the stannite group phases, were investigated in order to know the concentration and distribution of indium, and thus to point out the exploration potential of the SFD for this technology-critical element.

\section{Geological setting}

The SFD is located in the Oruro department at an altitude of 4,360 $\mathrm{m}$ above sea level. According to Lehmann et al. (1990), there is an asymmetric metal zonation perpendicular to the Andean strike that defines three major metallogenic belts, from west to east: (a) $\mathrm{Cu}-\mathrm{Mo}-\mathrm{Au}-\mathrm{Fe}$, Western Cordillera, (b) $\mathrm{Cu} \mathrm{Pb}-\mathrm{Zn}-\mathrm{Ag}-\mathrm{Au}$, Altiplano, and (c) Sn-W-Bi$\mathrm{Sb}-\mathrm{Ag}-\mathrm{Au}$, Eastern Cordillera. The SFD is located in the Central Andean tin belt, which in turn belongs to the Eastern Cordillera. According to Mlynarczyk and Williams-Jones (2005), tin mineralization in the Eastern Cordillera is related to discrete episodes of collisional interaction between Nazca and South American plates (Fig. 1). These authors have proposed a chronology in the formation of major ore deposits related to magmatism. Considering that, Western Cordillera ore-causative magmatism could have started at $31 \mathrm{Ma}$, inducing a remarkable Sn-W metallogenic event in many places along the Central Andean tin belt. In the SFD, Grant et al. (1979) assigned to the San Pablo stock an age of $\sim 23 \mathrm{Ma}$, while the eruptive complexes of Llallagua and Colquechaca $(\sim 100 \mathrm{~km}$ SE from SFD) have been dated at $\sim 21$ and $\sim 23$. Ma, respectively. The age of mineralization in Morococala was established at 20.1 $\pm 1.1 \mathrm{Ma}$ (Sugaki et al., 2003). A second, post-mineralization magmatic stage is represented by rhyolites of 7.0 Ma (Evernden et al., 1977) and dacites of 5.8-6.4 Ma (Lavenu et al., 1985).

The Japo mine is located at $32 \mathrm{~km}$ southeast of the city of Oruro. This deposit is situated at the eastern flank of the Santa Fe anticline axis, alligned NW-SE direction (Fig. 2). The country rocks in the Japo mine are represented by a Paleozoic meta-sedimentary sequence divided into the Cancañiri, Llallagua, Uncia and Catavi Formations. In general, the strata strike $\mathrm{N} 35^{\circ} \mathrm{W}$ with a general dip of $40^{\circ} \mathrm{NE}$ and an important fault strike $\mathrm{N} 20^{\circ} \mathrm{E}$. The ore minerals are hosted in quartz veins with variable thicknesses, from a few centimeters to several meters.

The igneous activity in the Santa Fe mining district is represented by the Morococala Formation, with two important episodes. The first one is mostly 


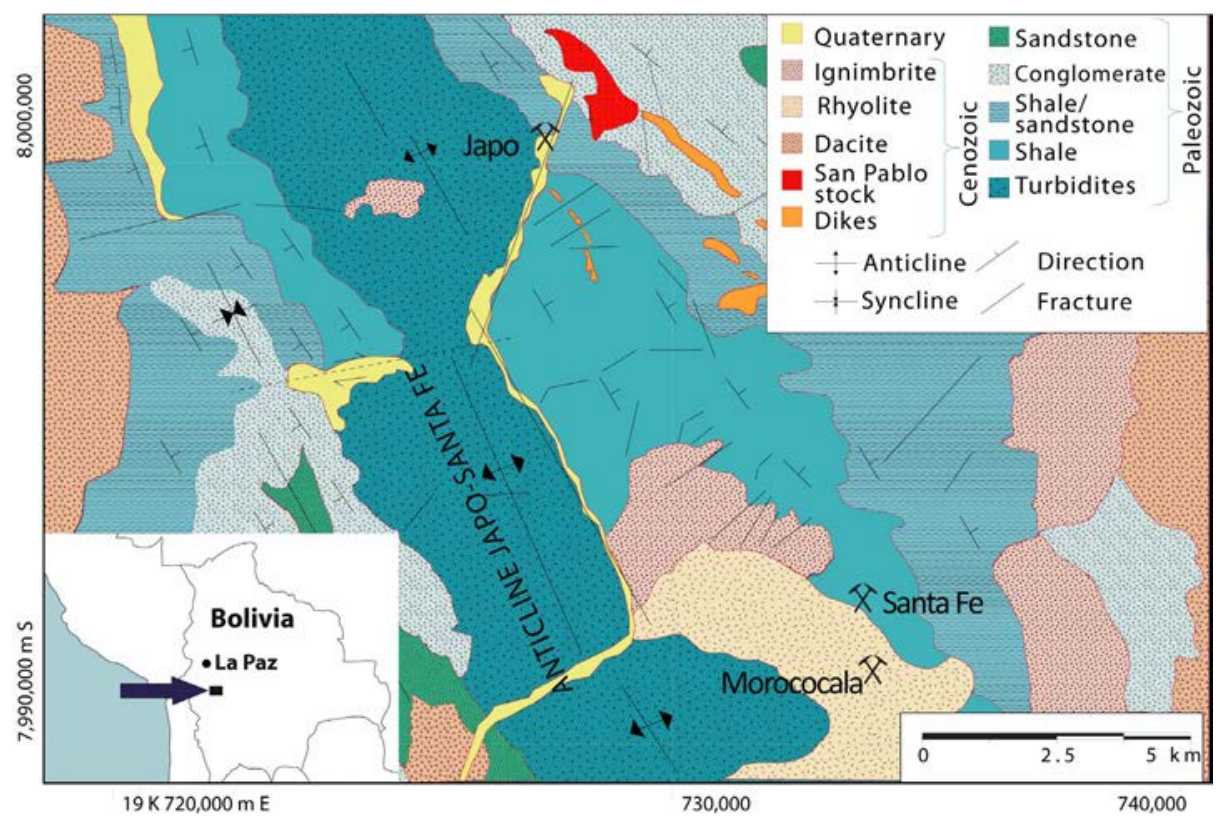

FIG. 2. Geological map of the Santa Fe District.

constituted by rhyolite of 7.0 Ma (Evernden et al., 1977) and dacite, of 5.8 to $6.4 \mathrm{Ma}$ (Lavenu et al., 1985). Generally, these are located at the top highland in Japo region, and they are more widely extended in Santa Fe-Morococala zone. On the other hand, an intense igneous activity, representing the second event, produced plutonic bodies as the San Pablo stock and related dikes. The age of this plutonic suite is Miocene (Sugaki et al., 2003). According with Sugaki et al. (1981) the thickness of the Morococala Formation is $>150 \mathrm{~m}$.

The Santa Fe and Morococala mines are separated one each other by $\sim 2 \mathrm{~km}$ (Fig. 2). They are mainly hosted by rocks of the Cancañiri Formation, which is unconformably covered by the Pliocene Morococala Formation.

The ore deposits in the SFD are spatially related to intrusive rocks, consisting of peraluminous granitic stocks and porphyritic intrusives formed through different magmatic pulses, most of them during Oligocene-Miocene times (Grant et al., 1979). The porphyritic intrusive rocks are mostly composed by phenocrys of quartz, K-feldspars, biotite, monazite and tourmaline, many of which are replaced by sulfides, chlorite and epidote. The main intrusive body is the San Pablo stock, which is exposed to the east of the Japo mine. It is an irregular body about $2 \mathrm{~km}$ long, which intruded the Paleozoic metasedimentary sequence. Dikes and hydrothermal breccias occur at the margin of the stock, cut by tin-bearing quartz veins. Sillitoe et al. (1975) classified the San Pablo stock as a quartz latite porphyry, noticing that it is pervasively altered, with the formation of sericite, pyrite, tourmaline and monazite.

The Paleozoic metasedimentary rock sequence starts in the SFD with the Amutara Formation, which is a shale and sandstone turbiditic unit deposited in a deep marine environment. The Silurian group overlies this unit; which includes the Cacañiri, Llallagua, Uncia and Catavi formations. The Cancañiri Formation conformably covers the Amutara Formation and is composed by micaceous sandstones and siltstones that gradually change to quartzites, sandstones, siltstones and grey-green shales of the Llallagua and Uncia formations. The Silurian group ends with the Catavi Formation, which consists of shales and sandstones (Sugaki et al., 1981).

An intense tectonic activity deformed the Paleozoic sequence and produced NNW-SSE folds, with the Santa Fe anticline as the largest one. Thrusting in the study area also took place; a wide $\mathrm{N}^{\mathrm{o}} 40 \mathrm{E}$ shear zone and two fracture systems were developed: (S1) $\mathrm{N} 40^{\circ} \mathrm{E}$ fracture system, dipping $60^{\circ} \mathrm{NW}$, and (S2) with the same direction but dipping $75^{\circ} \mathrm{SE}$. The Paleozoic 
sedimentary sequence is unconformably covered by the volcanic complex of the Morococala Formation, mainly constituted by calc-alkaline lavas and tuffs of Miocene age (Sugaki et al., 1981; Morgan et al., 1998). As a result of the fieldwork carried out in the present study, a more accurate geological map of the SFD is available (Fig. 2).

In the Japo deposit ore minerals occurr disseminated in intrusive rocks and also following lithological and structural contacts, fracture infillings and replacements (Figs. 3C, D, E). Hydrothermal alteration is developed (a) in plutonic rocks, where sericite, monazite, tourmaline and sulfides (mostly pyrite) were formed; and (b) along the contact between host rocks and quartz veins, where alunite, plumbojarosite, vermiculite, kaolinite and dickite occur.

On the other hand, in the Santa Fe and Morococala deposits, ore is found as quartz veins, of few centimeters to $0.5 \mathrm{~m}$ thick, with cassiterite, $\mathrm{Zn}-\mathrm{Pb}$ $\mathrm{Ag}$ sulfides and sulfosalts. Veins are associated to the above-mentioned fracture systems (S1 and S2), so that $\mathrm{S} 1$ hosts mostly Sn ores whereas $\mathrm{S} 2$ is rich in $\mathrm{Zn}-\mathrm{Pb}-\mathrm{Ag}$ (Fig. 3A). Rutile is associated with a late generation cassiterite, forming needle-like crystals (Fig. 3B). Among the supergene minerals, gypsum, calcite, melanterite and vivianite can be mentioned.

\section{Sampling and methods}

Both country rocks and ores were sampled in the Japo, Santa Fe and Morococala mines and outcrops. Additionally, 5,000 $\mathrm{m}$ of drill cores from the Japo mine were logged and sampled. For this study, 169 rock samples were collected in the SFD: 108 from drill cores, 38 in the mine and 23 in outcrops. Mineral assemblages were studied in 40 polished
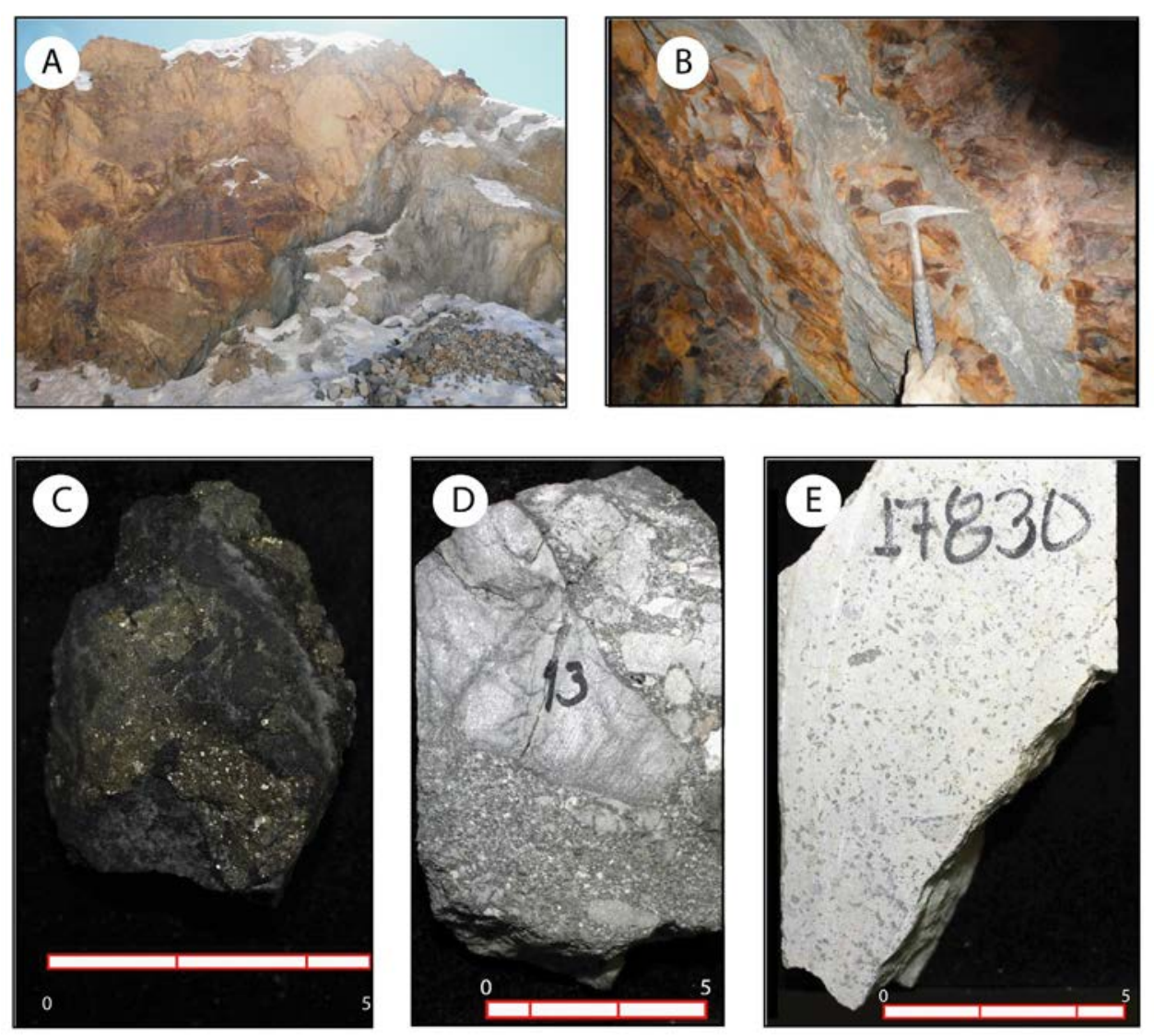

FIG. 3. Host rock and mineralization style in the Santa Fe District. A. Mineralized shear zone (gray color); B. Sulfides-bearing quartz vein in the Santa Fe mine; C. Ore minerals (Llallagua Fm.); D. Breccia with sulfides on matrix; E. Porphyry with sulfides replaced phenocrystals. 
thin sections using standard petrographic microscopy. Additionally, 30 polished ore sections were analyzed with a Hitachi TM-1000 table-top scanning electron microscope (SEM), at the Departament d'Enginyeria Minera, Industrial i TIC of the Universitat Politècnica de Catalunya and also in a ESEM Quanta 200 FEI, XTE 325/D8395 at the Serveis Cientícs i Tecnològics de la Universitat de Barcelona (CCiT-UB). This equipment allowed us to obtain back-scattered electron (BSE) images and qualitative chemical analyses by energy dispersive X-ray spectrometry (EDS). Quantitative analyses were obtained with an electron probe microanalyzer (EPMA) JEOL JXA8230 , at the CCiT-UB. The analyses were carried out under the following conditions: $20 \mathrm{KeV}, 20 \mathrm{nA}$, beam diameter of $1 \mu \mathrm{m}$, and a counting time of $30 \mathrm{~s}$; the used standards were skutterudite ( $\mathrm{NiK} \alpha, \mathrm{AsK} \alpha, \mathrm{FeK} \alpha$, $\mathrm{CoK} \alpha)$, sphalerite $(\mathrm{ZnK} \alpha, \mathrm{SnL} \alpha)$, cuprite $(\mathrm{CuK} \alpha)$, marcasite $(\mathrm{SK} \alpha)$, stibnite $(\mathrm{SbL} \alpha), \operatorname{Ag}(\mathrm{AgL} \alpha)$ and crocoite $(\mathrm{PbM} \alpha)$. The numbers of analyzed points were: cassiterite, 60; sphalerite, 70; stannite, 78; sakuraiite, 10; kërsterite, 4; and sulfosalts; 32 .

Bulk mineralogy was confirmed in 37 samples by X-ray diffraction (XRD). Spectra were obtained from powdered samples in a Bragg-Brentano PANAnalytical X'Pert 127 Diffractometer system (graphite monochromator, automatic 128-129 gap, Ka radiation of $\mathrm{Cu}$ at $\mathrm{k}=1.54061 \AA$, powered at $45 \mathrm{kV}, 40 \mathrm{~mA}$, scanning range $4-100^{\circ}$ of $2 \theta$ with a $0.017^{\circ} / 2 \mathrm{~h}$ step, 130 scan and a 50 -s measuring time) located at the CCiT-UB. The identification and semiquantitative evaluation of phases were conducted using the PANanalytical X'Pert HighScore software.

Bulk-rock analyses of element concentrations was carried out by a combination of instrumental analysis at the commercial laboratory ACTLABS. Standards measurement conditions and detection limits are described in 4Litho report (Actlab Ltd., 2017). Milling samples were carried out in an agate mill to avoid metals contamination. The ore was concentrated by gravity methods in the artisanal mines. Concentrate samples were also analyzed in order to compare values between host rocks and ore establishing the elemental distribution and mobility.

\section{Results}

\subsection{Metal and metalloid contents}

The igneous activity in the SFD is represented by the Morococala Formation, with two main stages. The latest formed the Miocene San Pablo stock (Sugaki et al., 2003) and a related dike swarm.

Metal and metalloid contents of the San Pablo quartz-latite stock and related dikes, as well as of the extrusive rocks and ore minerals of the SFD, are provided in table 1 and plotted in binary diagrams in figure 4. The San Pablo stock is anomalously rich

TABLE 1. GEOCHEMICAL COMPOSITION OF INTRUSIVE ROCKS, META-SEDIMENTARY HOST, ORE AND CONCENTRATE OF ORE MINERALS IN THE SANTA FE MINING DISTRICT.

\begin{tabular}{|c|c|c|c|c|c|c|c|c|c|c|c|c|}
\hline Element & Ga & $\mathrm{Cu}$ & As & Ag & In & Sn & $\mathbf{S b}$ & $\mathbf{W}$ & $\mathbf{P b}$ & $\mathbf{B i}$ & Zn & $\begin{array}{l}1,000 \\
\text { In/Zn }\end{array}$ \\
\hline Unit & ppm & ppm & ppm & ppm & ppm & ppm & ppm & ppm & ppm & ppm & $w t \%$ & \\
\hline $\begin{array}{l}\text { Average granitic } \\
\text { rocks (Hall, 1971) }\end{array}$ & 1.0 & 10.0 & 1.5 & - & - & 3.0 & - & 2.2 & 19 & - & 0.0039 & - \\
\hline San Pablo Stock & 47 & $<10$ & 67 & 0.7 & 2.5 & 404 & 29.1 & 21 & 82 & 2.4 & 0.01 & 417 \\
\hline Dome & 5 & $<10$ & 26 & 5.3 & 1.6 & 485 & 8.0 & 12 & 15 & 0.9 & 0.00 & 533 \\
\hline Dike & 7 & 20 & 34 & 5.0 & 2.2 & 532 & 4.8 & 16 & 35 & 9.1 & 0.00 & 733 \\
\hline Dike & 9 & 20 & 248 & 5.0 & 0.7 & 153 & 3.0 & 11 & 23 & 10.5 & 0.03 & 26 \\
\hline Host Rock & 15 & 70 & 1,160 & 20.0 & 1.0 & 186 & 4.4 & 14 & 41 & 16.6 & 0.01 & 100 \\
\hline Morococala ore & 35 & 30 & 593 & 11.6 & 54.5 & $>1,000$ & 89.9 & 39 & 1,060 & 101.0 & 0.04 & 1,298 \\
\hline $\begin{array}{l}\text { Morococala } \\
\text { concentrate }\end{array}$ & 30 & 740 & 202 & 4.5 & 125.0 & $>1,000$ & 41.8 & 31 & 3,490 & 8.1 & 1.00 & 125 \\
\hline $\begin{array}{l}\text { Morococala } \\
\text { concentrate } 2\end{array}$ & 33 & 80 & 176 & 24.6 & 200.0 & $>1,000$ & 141.0 & 407 & 1,330 & 69.0 & 0.11 & 1,852 \\
\hline Japo concentrate & 21 & 340 & 189 & 7.3 & 200.0 & $>1,000$ & 50.6 & 229 & 131 & 104.0 & 0.12 & 1,739 \\
\hline Japo concentrate 2 & 3 & 290 & 221 & 11.0 & 200.0 & $>1,000$ & 40.6 & 154 & 174 & 62.0 & 0.05 & 4,000 \\
\hline
\end{tabular}



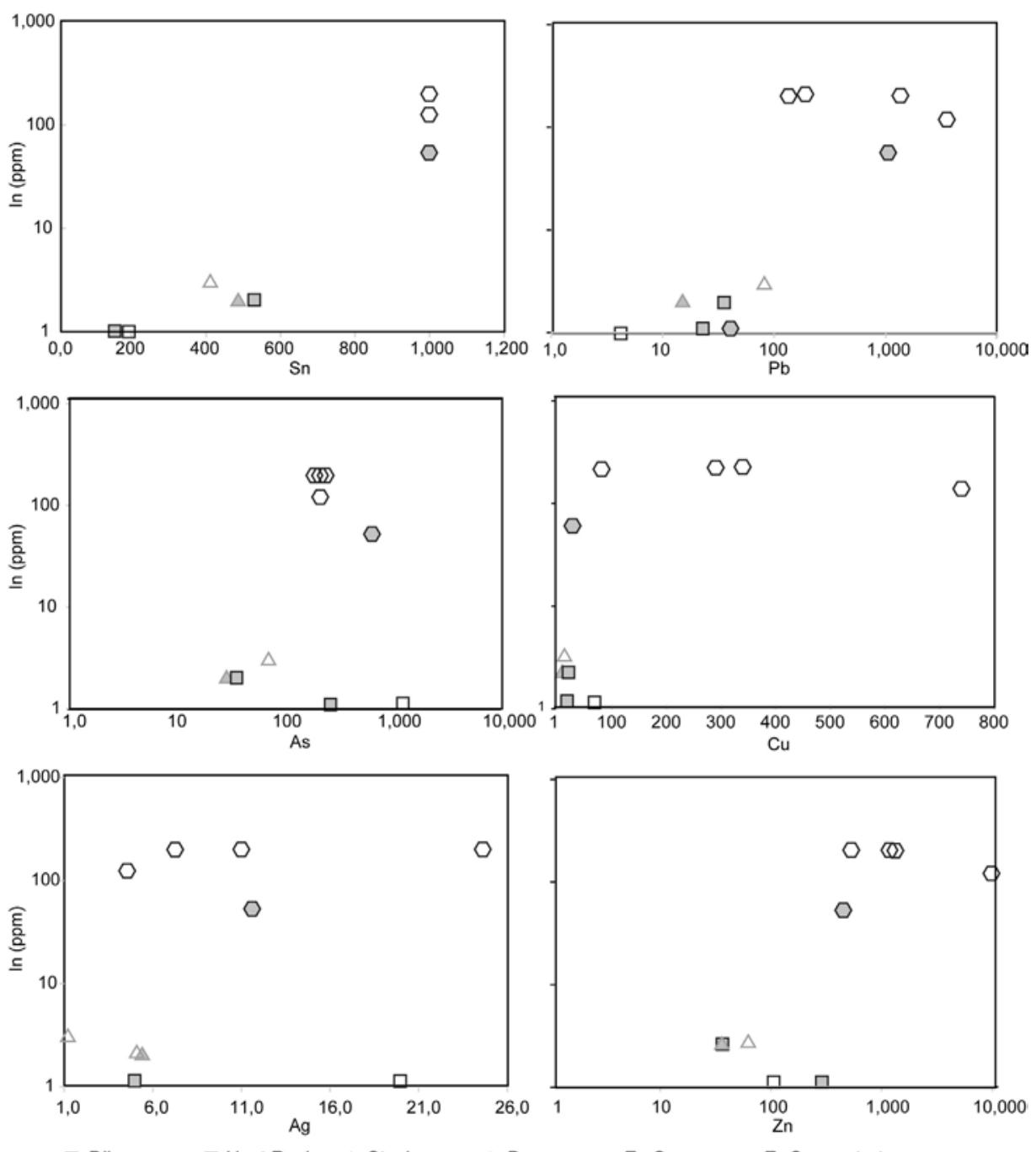

$\square$ Dike $\square$ Host Rock $\triangle$ Stock $\triangle$ Dome

O Ore

Concentrate

FIG. 4. Binary diagrams of $\mathrm{Sn}, \mathrm{Pb}, \mathrm{As}, \mathrm{Cu}, \mathrm{Ag}$ and $\mathrm{Zn}$ versus $\mathrm{In}$ in the igneous rock from the Santa Fe District, Bolivia.

in $\mathrm{Sn}, \mathrm{Ga}, \mathrm{As}, \mathrm{Cu}, \mathrm{Ag}, \mathrm{Zn}, \mathrm{W}$ and $\mathrm{Pb}$ all, relative to the average granitic rock (Turekian and Wedepohl, 1961; Hall, 1971). In the San Pablo stock, Sn and In contents are $404 \mathrm{ppm}$ and $2.5 \mathrm{ppm}$, respectively. In the ore concentrate, indium attains up to $200 \mathrm{ppm}$ and $\mathrm{Sn}$ exceeds $1,000 \mathrm{ppm}$.

Moreover, the $1,000 \times \mathrm{In} / \mathrm{Zn}$ ratio ranges from 25 (dike) up to 4,000 (concentrate), whereas in the San Pablo stock is 417. This ratio can be used as an estimate of the ability to form proper In-rich minerals; when $\mathrm{Zn}$ is abundant in an ore-forming system the ratios are likely low, thus In will precipitate in the sulfides lattice. With less $\mathrm{Zn}$ in the system, the ratio will become higher, leading to oversaturation of In and providing a high potential for other minerals to be formed (Cook et al., 2011a; Valkama et al., 2016).

\subsection{Paragenesis and mineral chemistry}

According with field and petrographic observations, two stages of mineralization can be distinguished in the SFD: (1) Early, Sn-rich mineralization, represented by cassiterite-quartz veins and disseminations (Figs. 5A and 5B), and (2) a late (more predominant), $\mathrm{Zn}-\mathrm{Pb}-\mathrm{Ag}$ mineralization, represented by veinlets with sphalerite, galena and stannite group phases 

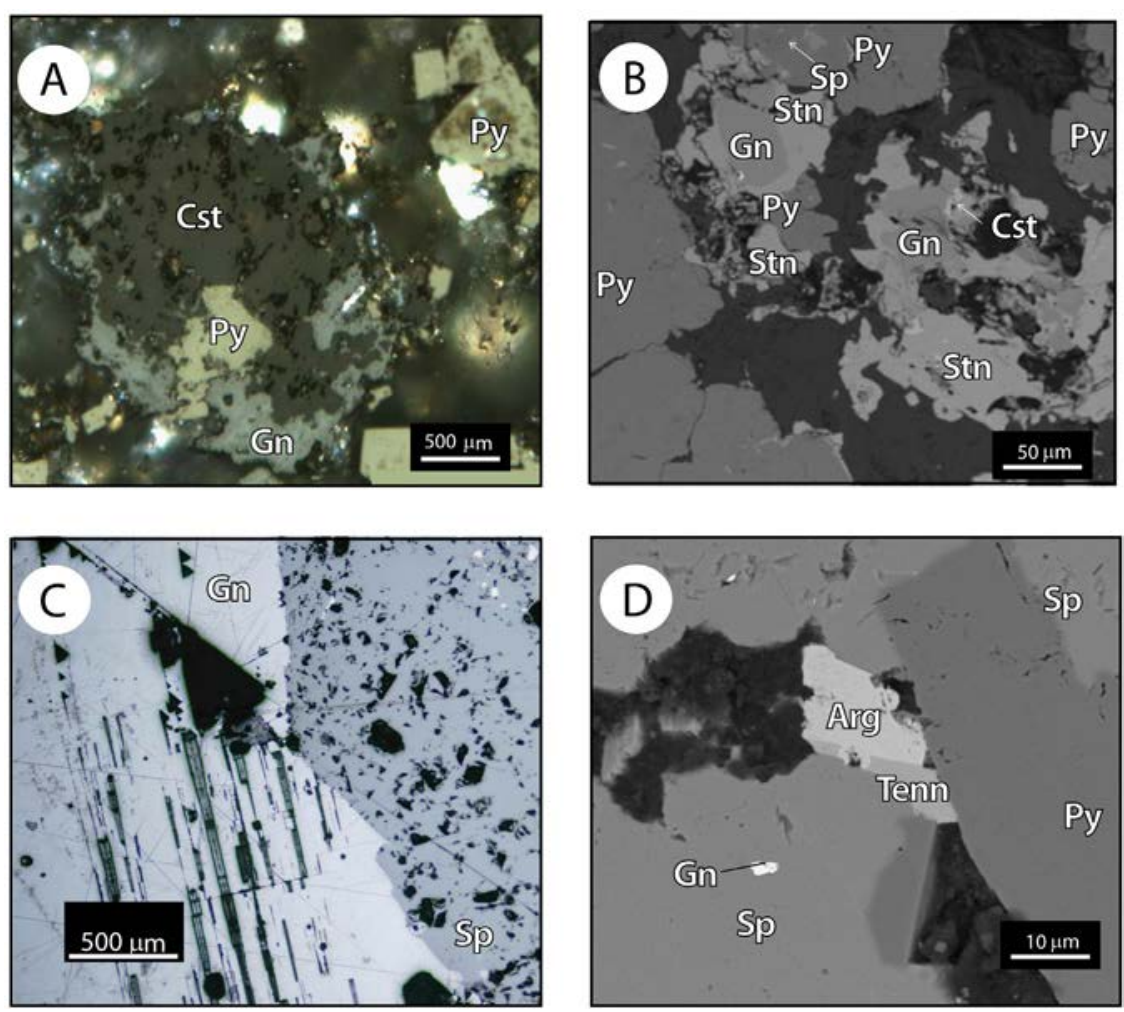

FIG. 5. A. Microphotography of the main mineral assemblage in the SFD under petrographic microscopy; B. Backscattered SEM images of the ore assemblage in the SFD; C. Microphotography of sphalerite and galena under petrographic microscopy; D. Backscattered electron SEM images of sulfosalts associated with galena, sphalerite and pyrite. Arg: argentite; Cst: cassiterite; Gn: galena; Py: pyrite; Sp: sphalerite; Stn: stannite; Tenn: tennantite.

(Figs. 5C and 5D). The former stage is more evident in the Japo deposit, while in Santa Fe and Morococala different generations of $\mathrm{Sn}$ and $\mathrm{Zn}-\mathrm{Pb}$ Ag mineralization are found.

\subsubsection{Oxides}

In the earliest stage of mineralization, cassiterite occurs in association with quartz, pyrite, arsenopyrite, chalcopyrite, chalcocite and, occasionally, galena and stannite. Cassiterite crystals are irregular in shape; in Santa Fe and Morococala they are smaller $(\sim 10 \mu \mathrm{m})$ than in Japo, where crystals up to few millimeters were found. Cassiterite has high iron contents, up to $3.23 \mathrm{wt} \%$ and the In content is between 0.09 and $0.25 \mathrm{wt} \%$, whereas $\mathrm{Ti}, \mathrm{Nb}, \mathrm{Ta}$ and $\mathrm{W}$ contents are negligible.

\subsubsection{Simple metal sulfides}

Galena and sphalerite are the most common sulfides. Galena occurs as euhedral crystals, up to $1 \mathrm{~cm}$ in size, commonly associated with sulfosalts (Fig. 6A). Chemical composition shows significant variations; EPMA analyses reveal an average content of $0.30 \mathrm{wt} \% \mathrm{Ag}$. Often, Ag-rich sulfides as argentite $\left(\mathrm{Ag}_{2} \mathrm{~S}\right)$ and matildite $\left(\mathrm{AgBiS}_{2}\right)$ are associated with galena, forming finegrained, complex intergrowths (Fig. 6C).

Sphalerite is the second ore mineral in abundance in the SFD, and occurs through all the mineralized zones. It develops anhedral grains, up to few $\mathrm{cm}$ across, with curvilinear equilibrium grain boundaries, forming mosaic aggregates and intergrowths with galena, pyrrhotite, pyrite and chalcopyrite (Figs. 5C, 5D). EPMA analyses of sphalerite reveal In contents, up to $0.26 \mathrm{wt} \%$ (Table 2), $\mathrm{Cd}$ up to $0.39 \mathrm{wt} \%$ and $\mathrm{Pb}$ up to $0.29 \mathrm{wt} \%$. Sphalerite analyses show a high inverse correlation $\left(\mathrm{r}^{2}=0.93\right)$ between $\mathrm{Fe}+\mathrm{Cu}+\mathrm{In}$ and $\mathrm{Zn}$ (Fig. 7).

Other sulfides are pyrite, arsenopyrite, pyrrhotite, stibnite and marcasite. Pyrite occurs in all deposits as grains, up to $5 \mathrm{~mm}$ in size, associated with quartz and 

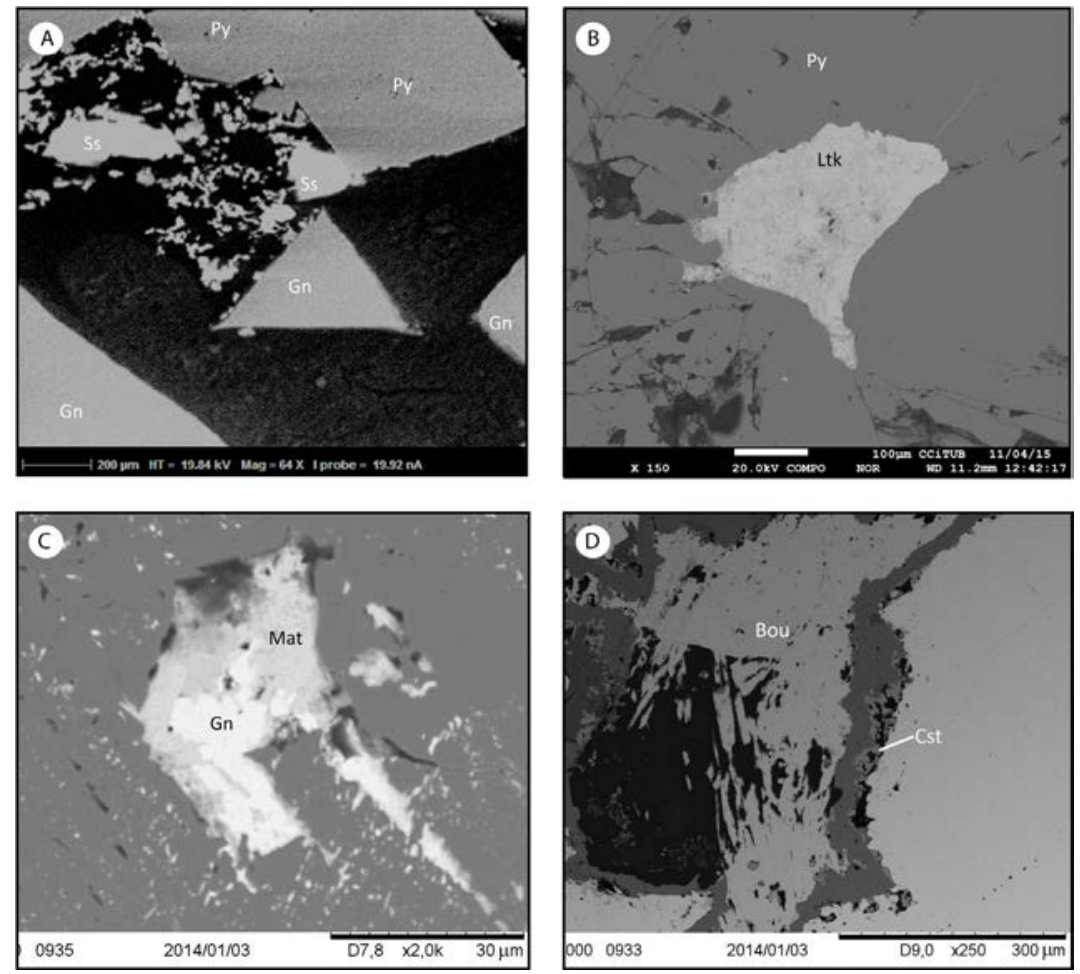

FIG. 6. Backscattered electron SEM images of sulfosalts of the SFD. A. Association of sulfosalts with galena and pyrite; B. Laitakarite e filling a cavity in a pyrite crystal; C. Matildite associated to galena in a cavity of a sphalerite crystal; D. Acicular crystals of boulangerite. Bou: boulangerite; Cst: cassiterite; Gn: galena; Ltk: laitakarite; Py: pyrite; Ss: sulfosalts; Mat: Matildite

TABLE 2. CHEMICAL COMPOSITION (wt\%) AND ATOMIC PROPORTIONS (APFU) OF SPHALERITE FROM THE SANTA FE MINING DISTRICT (EMPA).

\begin{tabular}{|c|c|c|c|c|c|c|c|c|c|c|c|c|}
\hline & \multicolumn{4}{|c|}{ Santa Fe Mine } & \multicolumn{8}{|c|}{ Morococala Mine } \\
\hline & 1 & 2 & 3 & 4 & 5 & 6 & 7 & 8 & 9 & 10 & 11 & 12 \\
\hline $\mathbf{S}$ & 33.63 & 32.76 & 34.62 & 33.90 & 34.72 & 34.49 & 34.34 & 34.34 & 34.55 & 34.37 & 35.36 & 34.49 \\
\hline $\mathbf{F e}$ & 9.58 & 9.27 & 8.64 & 5.65 & 7.71 & 11.04 & 10.89 & 10.82 & 11.36 & 11.35 & 11.93 & 11.11 \\
\hline $\mathrm{Cu}$ & 0.16 & 0.21 & 0.37 & 0.21 & 0.12 & 0.13 & 0.00 & 0.04 & 0.04 & 0.02 & 0.05 & 0.09 \\
\hline Zn & 56.22 & 57.09 & 54.31 & 58.92 & 56.54 & 53.86 & 54.55 & 54.51 & 53.69 & 53.93 & 51.96 & 54.10 \\
\hline Cd & 0.06 & 0.00 & 0.01 & 0.05 & 0.00 & 0.39 & 0.35 & 0.33 & 0.39 & 0.37 & 0.36 & 0.33 \\
\hline Sn & 0.00 & 0.00 & 0.52 & 0.39 & 0.00 & 0.00 & 0.00 & 0.00 & 0.00 & 0.00 & 0.00 & 0.00 \\
\hline In & 0.03 & 0.00 & 0.00 & 0.00 & 0.17 & 0.12 & 0.03 & 0.05 & 0.06 & 0.06 & 0.05 & 0.14 \\
\hline $\mathbf{P b}$ & 0.23 & 0.22 & 0.29 & 0.00 & 0.09 & 0.18 & 0.00 & 0.14 & 0.17 & 0.10 & 0.23 & 0.18 \\
\hline Total & 100.04 & 100.36 & 99.16 & 99.48 & 99.66 & 100.24 & 100.22 & 100.24 & 100.36 & 100.22 & 99.96 & 100.45 \\
\hline $\mathbf{S}$ & 1.049 & 1.022 & 1.080 & 1.057 & 1.083 & 1.075 & 1.071 & 1.071 & 1.077 & 1.072 & 1.103 & 1.075 \\
\hline $\mathbf{F e}$ & 0.172 & 0.166 & 0.155 & 0.101 & 0.138 & 0.198 & 0.195 & 0.194 & 0.203 & 0.203 & 0.214 & 0.199 \\
\hline $\mathrm{Cu}$ & 0.003 & 0.003 & 0.006 & 0.003 & 0.002 & 0.002 & 0.000 & 0.001 & 0.001 & 0.000 & 0.001 & 0.001 \\
\hline Zn & 0.860 & 0.873 & 0.830 & 0.901 & 0.864 & 0.823 & 0.834 & 0.833 & 0.821 & 0.824 & 0.794 & 0.827 \\
\hline Cd & 0.001 & 0.000 & 0.000 & 0.000 & 0.000 & 0.003 & 0.003 & 0.003 & 0.003 & 0.003 & 0.003 & 0.003 \\
\hline Sn & 0.000 & 0.000 & 0.004 & 0.003 & 0.000 & 0.000 & 0.000 & 0.000 & 0.000 & 0.000 & 0.000 & 0.000 \\
\hline In & 0.000 & 0.000 & 0.000 & 0.000 & 0.001 & 0.001 & 0.000 & 0.000 & 0.001 & 0.001 & 0.000 & 0.001 \\
\hline $\mathbf{P b}$ & 0.000 & 0.000 & 0.000 & 0.000 & 0.001 & 0.001 & 0.000 & 0.000 & 0.000 & 0.000 & 0.000 & 0.001 \\
\hline
\end{tabular}




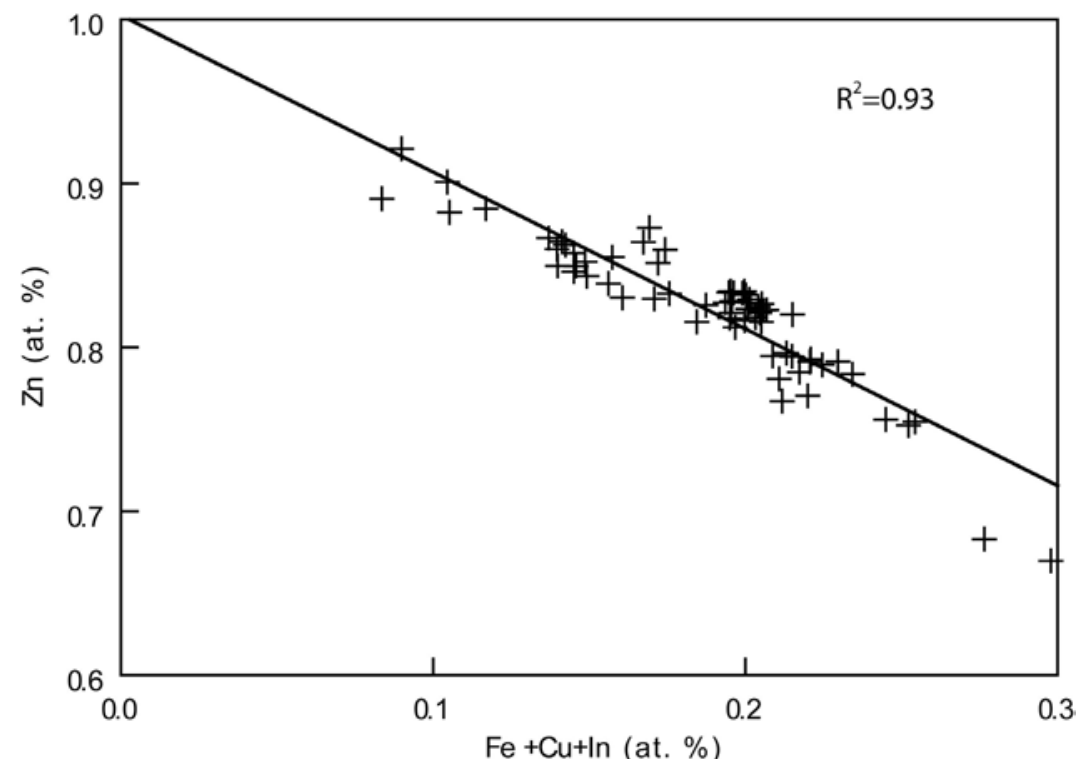

FIG. 7. Binary plots of $\mathrm{Zn}$ in sphalerite versus $\mathrm{Fe}+\mathrm{Cu}+\mathrm{In}$ from the Santa Fe District, Bolivia.

cassiterite and, occasionally, with galena, sphalerite, arsenopyrite, stannite and sulfosalts. Arsenopyrite crystals, up to a few millimeters in size, occur in association with pyrrhotite, covellite and marcasite. Some of them show anomalous anisotropy. Acicular stibnite and boulangerite crystals, up to several millimeters in size, are mostly filling cavities (Fig. 6D).

\subsubsection{Stannite Group}

In addition to cassiterite, Sn occurs in the SFD as a variety of minerals of the stannite group, namely stannite $\left(\mathrm{Cu}_{2} \mathrm{FeSnS}_{4}\right)$, kësterite $\left[\mathrm{Cu}_{2}(\mathrm{Zn}, \mathrm{Fe}) \mathrm{SnS}_{4}\right]$ and sakuraiite $\left[(\mathrm{Cu}, \mathrm{Zn}, \mathrm{Fe})_{3}(\mathrm{In}, \mathrm{Sn}) \mathrm{S}_{4}\right]$, as well as other sulfides of the S-Sn-Cu-Zn-Fe system (Shimizu et al., 1986; Seifert and Sandmann, 2006). Stannite is filling cavities and between the cleavage of silicates, in association with quartz and pyrite (Fig. 8). Stannite from Japo and Morococala is rich in Indium, up to $2.36 \mathrm{wt} \%$, whereas that of Santa Fe is depleted in this element (under the detection limit) (Table 3). Stannite group minerals are found in considerable amounts, but the grain size usually is $<100 \mu \mathrm{m}$. Kësterite is the most scarce; all analyzed crystals were obtained from Japo. Sakuraiite was found in Japo and, more widely distributed, in Morococala. It occurs as fine grains with composition corresponding to an intermediate member of the stannite and kërsterite trend solid solution, with structural formula between
$\left[\mathrm{Cu}_{1.9}(\mathrm{Fe}, \mathrm{Zn})_{1.0} \mathrm{Sn}_{1.0} \mathrm{~S}_{4.0}\right]$ and $\left[\mathrm{Cu}_{1.5}(\mathrm{Zn}, \mathrm{Fe})_{2.0} \mathrm{Sn}_{0.7} \mathrm{~S}_{4.0}\right]$. (Table 4). The highest In value, $2.03 \mathrm{wt} \%$, was found in sakuraiite from Morococala. In the Santa Fe mine, an Ag-rich (up to $39.47 \mathrm{wt} \%$ ) phase of the hocartitepirquitasite series $\left(\mathrm{Ag}_{2} \mathrm{FeSnS}_{4}-\mathrm{Ag}_{2} \mathrm{ZnSnS}_{4}\right)$ occurs. It forms crystals of $\sim 200 \mu \mathrm{m}$ in size, filling cavities associated to galena (Table 4).

In this study the sakuraiite formula was calculated as $\left[(\mathrm{Cu}, \mathrm{Zn}, \mathrm{Fe})_{3}(\mathrm{In}, \mathrm{Sn}) \mathrm{S}_{4}\right]$, according to that of Shimizu et al. (1986), although sakuraiite is also given as [(Cu,Zn,Fe,In,Sn)S] (e.g., Kissin and Owens, 1986). Stannite and kësterite formulas are also in discussion. Hall et al. (1978) proposed the name kësterite in stannite members when $\mathrm{Zn}>\mathrm{Fe}$. Crystals assignable to a solid solution among petrukite and stannoidite were also found.

\subsubsection{Sulfosalts}

A thorough analysis of sulfosalt phases was carried on in the mineralization of the SFD. An outstanding variety of phases has been determined, and they were grouped according to the proportion of $\mathrm{Sn}, \mathrm{Pb}, \mathrm{Ag}, \mathrm{Cu}, \mathrm{Sb}$ and $\mathrm{Bi}$ (Table 5). Several solid solutions were established, as $\left[\mathrm{Ag}(\mathrm{Zn}, \mathrm{Fe}) \mathrm{Bi}_{3} \mathrm{~S}_{6}\right]$, $\left[\mathrm{Cu}(\mathrm{Sn}, \mathrm{Fe})_{2} \mathrm{~S}_{4}\right]$ and $(\mathrm{PbBiAg})$.

Sn-rich sulfosalts such, as stannoidite $\left[\mathrm{Cu}_{8} \mathrm{Fe}_{3} \mathrm{Sn}_{2} \mathrm{~S}_{12}\right]$ and petrukite $\left[(\mathrm{Cu}, \mathrm{Fe}, \mathrm{Zn})_{2}(\mathrm{Sn}, \mathrm{In}) \mathrm{S}_{4}\right]$ were found. Franckeite series in the SFD occurs 

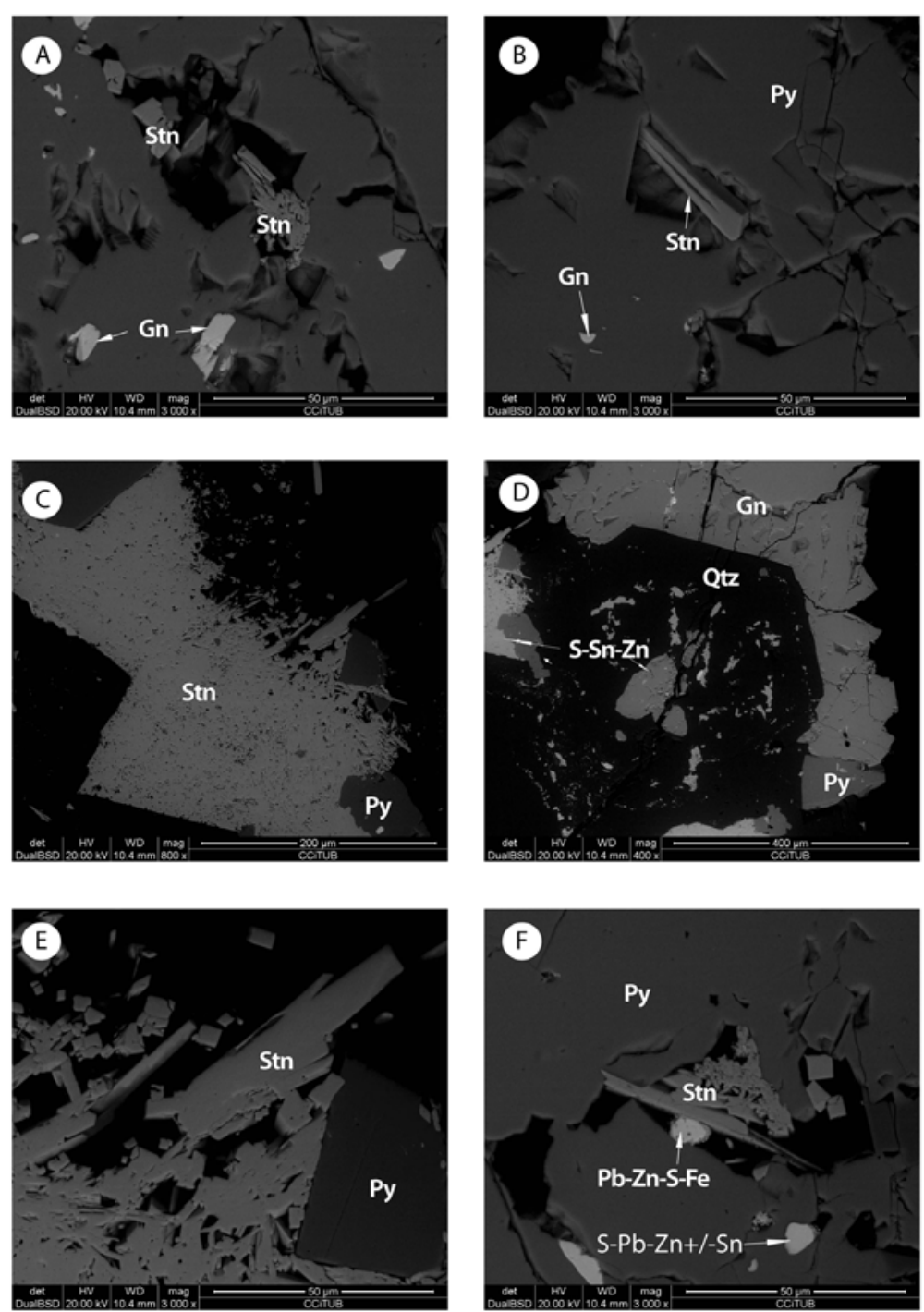

FIG. 8. Backscattered SEM images of: A. Stannite crystals filling cavities; B. Stannite crystals inside cleavage of a pyrite crystal; C. Prismatic crystals of stannite associated with pyrite; D. Ore minerals associated to euhedral quartz; E. Euhedral crystals of stannite showing tetrahedral prisms; F. minerals of stannite group with composition variable. Gn: galena; Py: pyrite; Qtz: quartz; Stn: stannite.

as potosiite $\left[\mathrm{Pb}_{6} \mathrm{FeSn}_{2} \mathrm{Sb}_{2} \mathrm{~S}_{14}\right]$ and franckeite $\left[(\mathrm{Pb}, \mathrm{Sn})_{6} \mathrm{FeSn}_{2} \mathrm{Sb}_{2} \mathrm{~S}_{14}\right]$. In addition, berndtite $\left(\mathrm{SnS}_{2}\right)$ (member of the melonite group) and teallite $\left(\mathrm{PbSnS}_{2}\right)$ can be mentioned.

A bunch of sulfosalts with silver was determined not only in the Santa Fe mine but also in the Morococala deposit. These include the tetrahedrite group, as tetrahedrite $\left[(\mathrm{Cu}, \mathrm{Fe})_{12} \mathrm{Sb}_{4} \mathrm{~S}_{13}\right]$, freibergite $\left[(\mathrm{Ag}, \mathrm{Cu}, \mathrm{Fe})_{12}(\mathrm{Sb}, \mathrm{As})_{4} \mathrm{~S}_{13}\right]$ and tennantite $\left[(\mathrm{Cu}, \mathrm{Fe})_{12} \mathrm{As}_{4} \mathrm{~S}_{13}\right]$. EPMA analyses of freibergite revealed up to $14.95 \mathrm{wt} \% \mathrm{Ag}$. Ag-Bi phases belonging (or related) to the lillianite group were recognized in Morococala, as gustavite $\left(\mathrm{PbAgBi}_{3} \mathrm{~S}_{6}\right)$, andorite $\left(\mathrm{PbAgSb}_{3} \mathrm{~S}_{6}\right)$ and ourayite $\left(\mathrm{Pb}_{4} \mathrm{Ag}_{3} \mathrm{Bi}_{5} \mathrm{~S}_{13}\right)$ (Fig. 9A, B). Ourayite crystals show up to $8.58 \mathrm{wt} \%$ Ag. Ahlfeld and Schneider-Scherbina (1964) reported miargyrite $\left(\mathrm{AgSbS}_{2}\right)$ in the Santa Fe mine; it was also recognized in samples of this study.

$\mathrm{Pb}$-rich sulfosalts are very fine, with grain size under $30 \mu \mathrm{m}$. They include cylindrite $\left(\mathrm{Pb}_{3} \mathrm{Sn}_{4} \mathrm{FeSb}_{2} \mathrm{~S}_{14}\right)$ 
TABLE 3. CHEMICAL COMPOSITION (Wt\%) AND ATOMIC PROPORTIONS (APFU) OF STANNITE FROM THE SANTA FE MINING DISTRICT (EMPA).

\begin{tabular}{|c|c|c|c|c|c|c|c|c|c|c|c|c|}
\hline \multicolumn{6}{|c|}{ Japo Mine } & \multicolumn{7}{|c|}{ Morococala Mine } \\
\hline & 1 & 2 & 3 & 4 & 5 & 6 & 7 & 8 & 9 & 10 & 11 & 12 \\
\hline $\mathbf{S}$ & 29.61 & 29.81 & 29.00 & 28.90 & 30.05 & 30.16 & 29.94 & 30.30 & 30.13 & 30.11 & 30.73 & 29.85 \\
\hline $\mathbf{F e}$ & 12.80 & 12.94 & 12.24 & 14.37 & 11.95 & 11.93 & 12.22 & 12.57 & 12.86 & 13.14 & 13.12 & 13.52 \\
\hline $\mathbf{C u}$ & 25.69 & 26.12 & 28.56 & 28.41 & 21.97 & 25.98 & 27.23 & 27.03 & 28.38 & 28.40 & 27.26 & 27.97 \\
\hline $\mathbf{Z n}$ & 7.10 & 6.82 & 2.01 & 2.57 & 17.03 & 5.53 & 3.30 & 3.13 & 1.55 & 1.47 & 2.44 & 1.54 \\
\hline As & 0.00 & 0.00 & 0.00 & 0.01 & 0.00 & 0.05 & 0.02 & 0.00 & 0.00 & 0.00 & 0.00 & 0.00 \\
\hline Se & 0.03 & 0.00 & 0.03 & 0.05 & 0.04 & 0.00 & 0.07 & 0.00 & 0.01 & 0.07 & 0.10 & 0.00 \\
\hline Ag & 0.18 & 0.00 & 0.08 & 0.00 & 0.08 & 0.68 & 0.34 & 0.61 & 0.33 & 0.38 & 0.47 & 0.44 \\
\hline Cd & 0.00 & 0.00 & 0.00 & 0.00 & 0.02 & 0.09 & 0.00 & 0.01 & 0.00 & 0.00 & 0.00 & 0.00 \\
\hline In & 0.20 & 0.18 & 0.20 & 0.11 & 0.14 & 0.34 & 0.31 & 0.36 & 0.45 & 0.41 & 0.00 & 0.01 \\
\hline Sn & 23.58 & 23.20 & 27.36 & 24.76 & 18.30 & 25.10 & 26.37 & 25.90 & 26.71 & 26.55 & 26.01 & 26.30 \\
\hline $\mathbf{N b}$ & 0.02 & 0.00 & 0.04 & 0.00 & 0.01 & 0.00 & 0.00 & 0.17 & 0.00 & 0.00 & 0.00 & 0.12 \\
\hline $\mathbf{P b}$ & 0.08 & 0.16 & 0.00 & 0.05 & 0.10 & 0.16 & 0.10 & 0.01 & 0.18 & 0.07 & 0.06 & 0.08 \\
\hline $\mathbf{B i}$ & 0.03 & 0.00 & 0.64 & 0.00 & 0.06 & 0.00 & 0.07 & 0.08 & 0.00 & 0.02 & 0.15 & 0.00 \\
\hline Total & 99.65 & 99.26 & 100.24 & 99.44 & 99.76 & 100.16 & 100.14 & 100.30 & 100.75 & 100.77 & 100.50 & 99.99 \\
\hline $\mathbf{S}$ & 3.998 & 4.000 & 3.998 & 3.997 & 3.998 & 4.000 & 4.000 & 4.000 & 4.000 & 4.000 & 4.000 & 4.000 \\
\hline $\mathrm{Fe}$ & 0.992 & 0.997 & 0.969 & 1.141 & 0.913 & 0.909 & 0.937 & 0.953 & 0.980 & 1.002 & 0.981 & 1.040 \\
\hline $\mathbf{C u}$ & 1.751 & 1.769 & 1.987 & 1.983 & 1.475 & 1.739 & 1.836 & 1.801 & 1.901 & 1.904 & 1.791 & 1.891 \\
\hline Zn & 0.470 & 0.449 & 0.136 & 0.174 & 1.111 & 0.360 & 0.216 & 0.203 & 0.101 & 0.096 & 0.156 & 0.101 \\
\hline As & 0.000 & 0.000 & 0.000 & 0.001 & 0.000 & 0.003 & 0.001 & 0.000 & 0.000 & 0.000 & 0.000 & 0.000 \\
\hline Ag & 0.007 & 0.000 & 0.003 & 0.000 & 0.003 & 0.027 & 0.013 & 0.024 & 0.013 & 0.015 & 0.018 & 0.017 \\
\hline Cd & 0.000 & 0.000 & 0.000 & 0.000 & 0.000 & 0.003 & 0.000 & 0.000 & 0.000 & 0.000 & 0.000 & 0.000 \\
\hline In & 0.008 & 0.007 & 0.008 & 0.004 & 0.005 & 0.013 & 0.012 & 0.013 & 0.017 & 0.015 & 0.000 & 0.000 \\
\hline Sn & 0.860 & 0.841 & 1.019 & 0.925 & 0.658 & 0.899 & 0.952 & 0.924 & 0.958 & 0.953 & 0.915 & 0.952 \\
\hline
\end{tabular}

and phases of $\left(\mathrm{SbS}_{3}\right)$ series as boulangerite $\left(\mathrm{Pb}_{5} \mathrm{Sb}_{4} \mathrm{~S}_{11}\right)$, jamesonite $\left(\mathrm{Pb}_{4} \mathrm{FeSb}_{6} \mathrm{~S}_{14}\right)$ and zinckenite $\left(\mathrm{Pb}_{9} \mathrm{Sb}_{22} \mathrm{~S}_{42}\right)$. Viaeneite $\left[(\mathrm{Fe}, \mathrm{Pb})_{4} \mathrm{~S}_{8} \mathrm{O}\right]$ is an unusual oxysulfide that was also recognized in Santa Fe. Until now, it had only been reported by Kucha et al. (1996).

Bismuthinite $\left(\mathrm{Bi}_{2} \mathrm{~S}_{3}\right)$ and bismite $\left(\mathrm{Bi}_{2} \mathrm{O}_{3}\right)$ crystals found in the SFD are elongated, of $\sim 50 \mu \mathrm{m}$ in length (Fig. 9C). Cosalite $\left(\mathrm{Pb}_{2} \mathrm{Bi}_{2} \mathrm{~S}_{5}\right)$ was recognized in Morococala. It belongs to lead-bismuth sulfosalts and accepts substitutions of $\mathrm{Cu}, \mathrm{Ag}, \mathrm{Pb}$ and $\mathrm{Bi}$ (Topa and Makovicky, 2010). Cosalite from the SFD shows substitution of Bi by As.

\subsubsection{Phosphates}

Phosphates occur in cavities and small fractures; have been formed during two different stages: (a) an earlier, metasomatism stage, where monazite [(Ce, La, Nd,Th) $\left.\mathrm{PO}_{4}\right]$ was formed (Fig. 9D), and (b) a later, supergene alteration stage, with plumbogummite $\left[\mathrm{PbAl}_{3}\left(\mathrm{PO}_{4}\right)_{2}(\mathrm{OH})_{5} \cdot\left(\mathrm{H}_{2} \mathrm{O}\right)\right]$ and crandallite $\left[\mathrm{CaAl}_{3}\left(\mathrm{PO}_{4}\right)_{2}(\mathrm{OH})_{5} \cdot\left(\mathrm{H}_{2} \mathrm{O}\right)\right]$.

\subsection{Alteration}

Hydrotermal alteration in the SFD was studied by X-ray diffraction. Several samples, related to the ore deposits, were analyzed in order to recognize cryptocrystalline or clay minerals. The terms used to classify alterations can be expressed as a function of recognized mineral assemblages. In the mineral assemblage presented here, minerals are listed in order of decreasing abundance (Table 6). Advance argillic alteration was recognized in the Japo and Morococala deposits, where kaolinite and dickite \pm alunite or pyrite was found. Argillic alteration is more evident in the Santa Fe deposit, where kaolinite is associated with sericite, potassic alteration was found in samples from the Japo and 
TABLE 4. CHEMICAL COMPOSITION (WT\%) AND ATOMIC PROPORTIONS (APFU) OF COMPOSITION AND ATOMIC PROPORTIONS OF SAKURAIITE AND KËRSTERITE FROM THE SANTA FE MINING DISTRICT (EMPA).

\begin{tabular}{|c|c|c|c|c|c|c|c|c|c|c|c|c|}
\hline & \multicolumn{10}{|c|}{ SAKURAIITE } & \multirow{2}{*}{\multicolumn{2}{|c|}{$\begin{array}{c}\text { KËRSTERITE } \\
\text { Japo Mine }\end{array}$}} \\
\hline & \multicolumn{3}{|c|}{ Japo Mine } & \multicolumn{7}{|c|}{ Morococala Mine } & & \\
\hline & 1 & 2 & 3 & 4 & 5 & 6 & 7 & 8 & 9 & 10 & 1 & 2 \\
\hline $\mathbf{S}$ & 29.50 & 30.05 & 29.62 & 29.24 & 31.07 & 30.63 & 27.26 & 30.18 & 31.57 & 31.11 & 29.02 & 30.05 \\
\hline $\mathbf{F e}$ & 14.03 & 11.95 & 11.66 & 12.50 & 13.00 & 12.75 & 14.94 & 14.04 & 12.65 & 13.01 & 12.76 & 11.95 \\
\hline $\mathrm{Cu}$ & 25.14 & 21.97 & 22.62 & 25.12 & 21.95 & 25.72 & 21.79 & 27.54 & 21.68 & 22.51 & 21.88 & 21.97 \\
\hline $\mathbf{Z n}$ & 6.19 & 17.03 & 10.80 & 1.62 & 12.17 & 5.92 & 1.40 & 1.84 & 14.58 & 13.50 & 12.81 & 17.03 \\
\hline As & 0.00 & 0.00 & 0.00 & 0.00 & 0.00 & 0.00 & 0.08 & 0.05 & 0.03 & 0.00 & 0.00 & 0.00 \\
\hline Se & 0.07 & 0.04 & 0.10 & 0.00 & 0.00 & 0.05 & 0.00 & 0.00 & 0.11 & 0.00 & 0.05 & 0.01 \\
\hline Ag & 0.09 & 0.08 & 0.10 & 0.86 & 0.75 & 0.78 & 0.51 & 0.85 & 0.73 & 0.34 & 0.00 & 0.08 \\
\hline Cd & 0.00 & 0.02 & 0.00 & 0.00 & 0.05 & 0.05 & 0.11 & 0.00 & 0.00 & 0.08 & 0.08 & 0.02 \\
\hline In & 0.12 & 0.14 & 0.14 & 0.90 & 2.03 & 1.68 & 0.07 & 0.08 & 0.19 & 0.23 & 0.13 & 0.14 \\
\hline Sn & 24.21 & 18.30 & 23.12 & 24.93 & 20.30 & 24.26 & 20.26 & 26.67 & 20.71 & 20.39 & 20.24 & 18.30 \\
\hline $\mathbf{P b}$ & 0.03 & 0.10 & 0.19 & 0.03 & 0.10 & 0.02 & 0.11 & 0.05 & 0.08 & 0.05 & 0.07 & 0.10 \\
\hline Total & 99.42 & 99.76 & 98.42 & 95.22 & 101.56 & 102.00 & 88.32 & 101.45 & 102.64 & 101.54 & 97.11 & 99.76 \\
\hline $\mathbf{S}$ & 3.996 & 3.998 & 3.995 & 4.000 & 4.000 & 4.000 & 4.000 & 4.000 & 4.000 & 4.000 & 3.997 & 3.999 \\
\hline $\mathrm{Fe}$ & 1.091 & 0.913 & 0.903 & 0.982 & 0.961 & 0.956 & 1.259 & 1.069 & 0.920 & 0.961 & 1.009 & 0.913 \\
\hline $\mathrm{Cu}$ & 1.719 & 1.475 & 1.539 & 1.734 & 1.426 & 1.695 & 1.614 & 1.842 & 1.386 & 1.461 & 1.521 & 1.476 \\
\hline $\mathbf{Z n}$ & 0.411 & 1.111 & 0.714 & 0.109 & 0.768 & 0.379 & 0.101 & 0.120 & 0.906 & 0.851 & 0.865 & 1.111 \\
\hline As & 0.000 & 0.000 & 0.000 & 0.000 & 0.000 & 0.000 & 0.005 & 0.003 & 0.002 & 0.000 & 0.000 & 0.000 \\
\hline Ag & 0.004 & 0.003 & 0.004 & 0.035 & 0.029 & 0.030 & 0.022 & 0.034 & 0.027 & 0.013 & 0.000 & 0.003 \\
\hline $\mathrm{Cd}$ & 0.000 & 0.001 & 0.000 & 0.000 & 0.002 & 0.002 & 0.005 & 0.000 & 0.000 & 0.003 & 0.000 & 0.000 \\
\hline In & 0.005 & 0.005 & 0.005 & 0.034 & 0.073 & 0.061 & 0.003 & 0.003 & 0.007 & 0.008 & 0.005 & 0.005 \\
\hline Sn & 0.886 & 0.658 & 0.842 & 0.921 & 0.706 & 0.856 & 0.803 & 0.955 & 0.709 & 0.708 & 0.753 & 0.658 \\
\hline
\end{tabular}

Santa Fe deposits, where orthoclase or biotite is present. Finally, an association of sericite, monazite and cassiterite \pm Sphalerite, rutile, hematite and quartz represents greisen alteration.

\section{Discussion}

\subsection{Paragenetic sequence and type of deposit}

The mineralization processes in the SFD are related to hydrothermal activity, since it is formed in or around the stock or dikes and the host rocks to the ore deposits are hydrothermally altered. The San Pablo stock shows replacement of phenocrysts by aggregates of cassiterite and sulfides. These textures suggest that mineral deposition started in the last stage of the intrusive activity emplacement. The sequence of crystallization of the ore minerals in the SFD is shown in figure 10.
The economic mineralization in the SFD is associated with the San Pablo stock (Turneaure, 1960; Ahlfeld, 1967; Sillitoe et al., 1975; Grant et al., 1979; Sugaki et al., 2003; Mlynarczyk and WilliamsJones, 2005). The San Pablo stock has a primary association of quartz-feldspars-biotite; K-feldspar phenocrysts appear replaced by tourmaline, pyrite, and cassiterite accompanied by variable amounts of rutile and monazite (Figs. 3E and 9D). Moreover, mineral association typical of argillic, advanced argillic, potassic, and greisen type alteration has been detected around the ore deposits in the SFD.

Burt (1981) defined greisen as hydrothermally altered granitic rocks characterized by an association of quartz and micas with variable topaz, tourmaline and fluorite or other F- or B-rich minerals. Greisens result from complex metasomatic processes that affect and take place within a nearly granitic mass and the adjacent country rocks (Pirajno, 2009). 
TABLE 5. SUMMARY OF SULFOSALTS FROM THE SANTA FE MINING DISTRICT (EMPA) AND THEIR STRUCTURAL FORMULA.

\begin{tabular}{|c|c|c|c|c|c|}
\hline $\begin{array}{l}\text { Mineralogical } \\
\text { Group }\end{array}$ & $\begin{array}{l}\text { Mineral } \\
\text { Name }\end{array}$ & $\mathbf{n}$ & This study & Formula & Reference \\
\hline \multirow{6}{*}{$\begin{array}{l}\text { Stannite } \\
\text { Group }\end{array}$} & Stannite & 78 & $\mathrm{Cu}_{1.9}(\mathrm{Fe}, \mathrm{Zn})_{1.0} \mathrm{Sn}_{1.0} \mathrm{~S}_{4.0}$ & $\mathrm{Cu}_{2}(\mathrm{Fe}, \mathrm{Zn}) \mathrm{SnS}_{4}$ & Hall et al. (1978) \\
\hline & Kësterite & 4 & $\mathrm{Cu}_{1.5}(\mathrm{Zn}, \mathrm{Fe})_{2.0} \mathrm{Sn}_{0.7} \mathrm{~S}_{4.0}$ & $\mathrm{Cu}_{2}(\mathrm{Zn}, \mathrm{Fe}) \mathrm{SnS}_{4}$ & Hall et al. (1978) \\
\hline & Sakuraiite & 10 & $(\mathrm{Cu}, \mathrm{Zn}, \mathrm{Fe})_{3.2}(\mathrm{In}, \mathrm{Sn})_{0.8} \mathrm{~S}_{4.0}$ & $(\mathrm{Cu}, \mathrm{Zn}, \mathrm{Fe})_{3}(\mathrm{In}, \mathrm{Sn}) \mathrm{S}_{4}$ & Shimizu et al. (1986) \\
\hline & Hocartite & 3 & $\mathrm{Ag}_{1.9} \mathrm{Fe}_{06} \mathrm{Zn}_{0.2} \mathrm{Cu}_{0.1} \mathrm{Sn}_{1.0} \mathrm{~S}_{4.0}$ & $\mathrm{Ag}_{2} \mathrm{FeSnS}_{4}$ & Fleischer (1969) \\
\hline & Pirquitasite & 2 & $\mathrm{Ag}_{1.9} \mathrm{Zn}_{0.9} \mathrm{Sn}_{1.0} \mathrm{~S}_{4.0}$ & $\mathrm{Ag}_{2} \mathrm{ZnSnS}_{4}$ & Johan and Picot (1982) \\
\hline & Petrukite & 7 & $(\mathrm{Cu}, \mathrm{Ag})_{1.95}(\mathrm{Fe}, \mathrm{Zn})_{1.2}(\mathrm{Sn}, \mathrm{In})_{0.98} \mathrm{~S}_{4.0}$ & $(\mathrm{Cu}, \mathrm{Ag})_{2}(\mathrm{Fe}, \mathrm{Zn})(\mathrm{Sn}, \mathrm{In}) \mathrm{S}_{4}$ & Petruk (1973) \\
\hline \multirow{2}{*}{$\begin{array}{l}\text { Franckeite } \\
\text { Group }\end{array}$} & Franckeite & 8 & $\mathrm{Fe}^{2+}{ }_{1.1}\left(\mathrm{~Pb}, \mathrm{Sn}^{2+}\right)_{6.1} \mathrm{Sn}_{2.0}{ }^{4+} \mathrm{Sb} 2,0 \mathrm{~S}_{14.0}$ & $\mathrm{Fe}^{2+}\left(\mathrm{Pb}, \mathrm{Sn}^{2+}\right)_{6} \mathrm{Sn}_{2}^{4+} \mathrm{Sb}_{2} \mathrm{~S}_{14}$ & Williams and Hyde (1988) \\
\hline & Potosíite & 6 & $\mathrm{~Pb}_{6.3} \mathrm{Sn}_{2.7} \mathrm{Fe}_{1.9} \mathrm{Sb}_{2.3} \mathrm{~S}_{16.0}$ & $\mathrm{~Pb}_{6} \mathrm{Sn}_{3} \mathrm{FeSb}_{3} \mathrm{~S}_{16}$ & Williams and Hyde (1988) \\
\hline $\begin{array}{l}\text { Melanite } \\
\text { Group }\end{array}$ & Berndtite & 1 & & $\mathrm{SnS}_{2}$ & Moh and Berndt (1964) \\
\hline \multirow{3}{*}{$\begin{array}{l}\text { Tethraedrite } \\
\text { group }\end{array}$} & Tethraedrite & 1 & & $\mathrm{Cu}_{12} \mathrm{Sb}_{4} \mathrm{~S}_{13}$ & Johnson et al. (1988) \\
\hline & Freibergite & 1 & $\mathrm{Ag} 2.5 \mathrm{Cu} 7.3 \mathrm{Fe}_{2.0} \mathrm{Sb} 3.9 \mathrm{~S}_{13.0}$ & $\mathrm{Ag}_{6} \mathrm{Cu}_{4} \mathrm{Fe}_{2} \mathrm{Sb}_{4} \mathrm{~S}_{13-\mathrm{x}}$ & Fleischer et al. (1975) \\
\hline & Tennantite & 1 & $(\mathrm{Cu}, \mathrm{Fe})_{12} \mathrm{As}_{4} \mathrm{~S}_{13}$ & $\mathrm{Cu}_{12} \mathrm{As}_{4} \mathrm{~S}_{13}$ & Seal et al.(1990) \\
\hline \multirow[t]{3}{*}{$\begin{array}{l}\text { Lillianite } \\
\text { Group }\end{array}$} & Gustavite & 2 & $\mathrm{Ag}_{0.3} \mathrm{~Pb}_{2.2} \mathrm{Bi}_{1.5} \mathrm{~S}_{5.9}$ & $\mathrm{AgPbBi}_{3} \mathrm{~S}_{6}$ & $\begin{array}{l}\text { Makovicky and Karup-Møller } \\
\text { (1977) }\end{array}$ \\
\hline & Ourayite & 2 & $\mathrm{Ag}_{2.0} \mathrm{~Pb}_{3.3} \mathrm{Bi}_{4.9} \mathrm{~S}_{13.0}$ & $\mathrm{Ag}_{3} \mathrm{~Pb}_{4} \mathrm{Bi}_{5} \mathrm{~S}_{13}$ & $\begin{array}{l}\text { Makovicky and Karup-Møller } \\
\text { (1977) }\end{array}$ \\
\hline & Andorite & 1 & & $\mathrm{AgPbSb}_{3} \mathrm{~S}_{6}$ & $\begin{array}{l}\text { Makovicky and Karup-Møller } \\
\text { (1977) }\end{array}$ \\
\hline $\begin{array}{l}\text { Cylindrite } \\
\text { group }\end{array}$ & Cylindrite & 4 & $\mathrm{Fe}_{1.4} \mathrm{~Pb}_{5.3} \mathrm{Sn}_{2.8} \mathrm{Sb}_{2.0} \mathrm{~S}_{14.0}$ & $\mathrm{FePb}_{3} \mathrm{Sn}_{4} \mathrm{Sb}_{2} \mathrm{~S}_{14}$ & Williams and Hyde (1988) \\
\hline \multirow[t]{14}{*}{ Stibnite Group } & Stibnite & 1 & & $\mathrm{Sb}_{2} \mathrm{~S}_{3}$ & Kuze et al. (2004) \\
\hline & Bismuthinite & 18 & $\mathrm{Bi}_{1.9} \mathrm{~S}_{3.0}$ & $\mathrm{Bi}_{2} \mathrm{~S}_{3}$ & Kuze et al. (2004) \\
\hline & Stannoidite & 1 & & $\mathrm{Cu}_{8}(\mathrm{Fe}, \mathrm{Zn})_{3} \mathrm{Sn}_{2} \mathrm{~S}_{12}$ & Fleischer (1969) \\
\hline & Teallite & 1 & $\mathrm{~Pb}_{2.0} \mathrm{Sn}_{1.6} \mathrm{~S}_{2.0}$ & $\mathrm{PbSnS}_{2}$ & Ahlfeld (1926) \\
\hline & Argentite & 4 & $\mathrm{Ag}_{1.5} \mathrm{~S}_{1.0}$ & $\mathrm{Ag}_{2} \mathrm{~S}$ & Petruk et al. (1974) \\
\hline & Matildite & 5 & $\mathrm{Ag}_{0.7} \mathrm{Bi}_{1.9} \mathrm{~S}_{4.0}$ & $\mathrm{AgBiS}_{2}$ & Shimizu et al. (1998) \\
\hline & Myargyrite & 1 & & $\mathrm{AgSbS}_{2}$ & Effenberger et al. (2002) \\
\hline & Boulangerite & 1 & & $\mathrm{~Pb}_{5} \mathrm{Sb}_{4} \mathrm{~S}_{11}$ & Kharbish and Jeleň (2016) \\
\hline & Jamesonite & 4 & $\mathrm{Fe}_{1.9} \mathrm{~Pb}_{3.8} \mathrm{Sb}_{5.7} \mathrm{~S}_{14.0}$ & $\mathrm{FePb}_{4} \mathrm{Sb}_{6} \mathrm{~S}_{14}$ & Kharbish and Jeleň (2016) \\
\hline & Zinckerite & 1 & & $\mathrm{~Pb}_{9} \mathrm{Sb}_{22} \mathrm{~S}_{42}$ & Kharbish and Jeleň (2016) \\
\hline & Viaeneite & 1 & $\mathrm{Fe}_{3.9} \mathrm{~Pb}_{0.3} \mathrm{~S}_{8.0} \mathrm{O}_{1.0}$ & $(\mathrm{Fe}, \mathrm{Pb})_{4} \mathrm{~S}_{8} \mathrm{O}$ & Kucha et al. (1996) \\
\hline & Laitakarite & 1 & $\mathrm{Bi}_{3.1} \mathrm{Se}_{3.3}$ & $\mathrm{Bi}_{4} \mathrm{Se}_{3}$ & Cook et al. (2007) \\
\hline & Cosalite & 3 & $\mathrm{~Pb}_{2.3} \mathrm{Bi}_{1.5} \mathrm{~S}_{5.9}$ & $\mathrm{~Pb}_{2} \mathrm{Bi}_{2} \mathrm{~S}_{5}$ & $\begin{array}{l}\text { Sugaki et al. (1982) } \\
\text { Topa and Makovicky (2010) }\end{array}$ \\
\hline & Bismite & 12 & $\mathrm{Bi}_{1.3} \mathrm{O}_{3.0}$ & $\mathrm{Bi}_{2} \mathrm{O}_{3}$ & Frondel (1943) \\
\hline
\end{tabular}



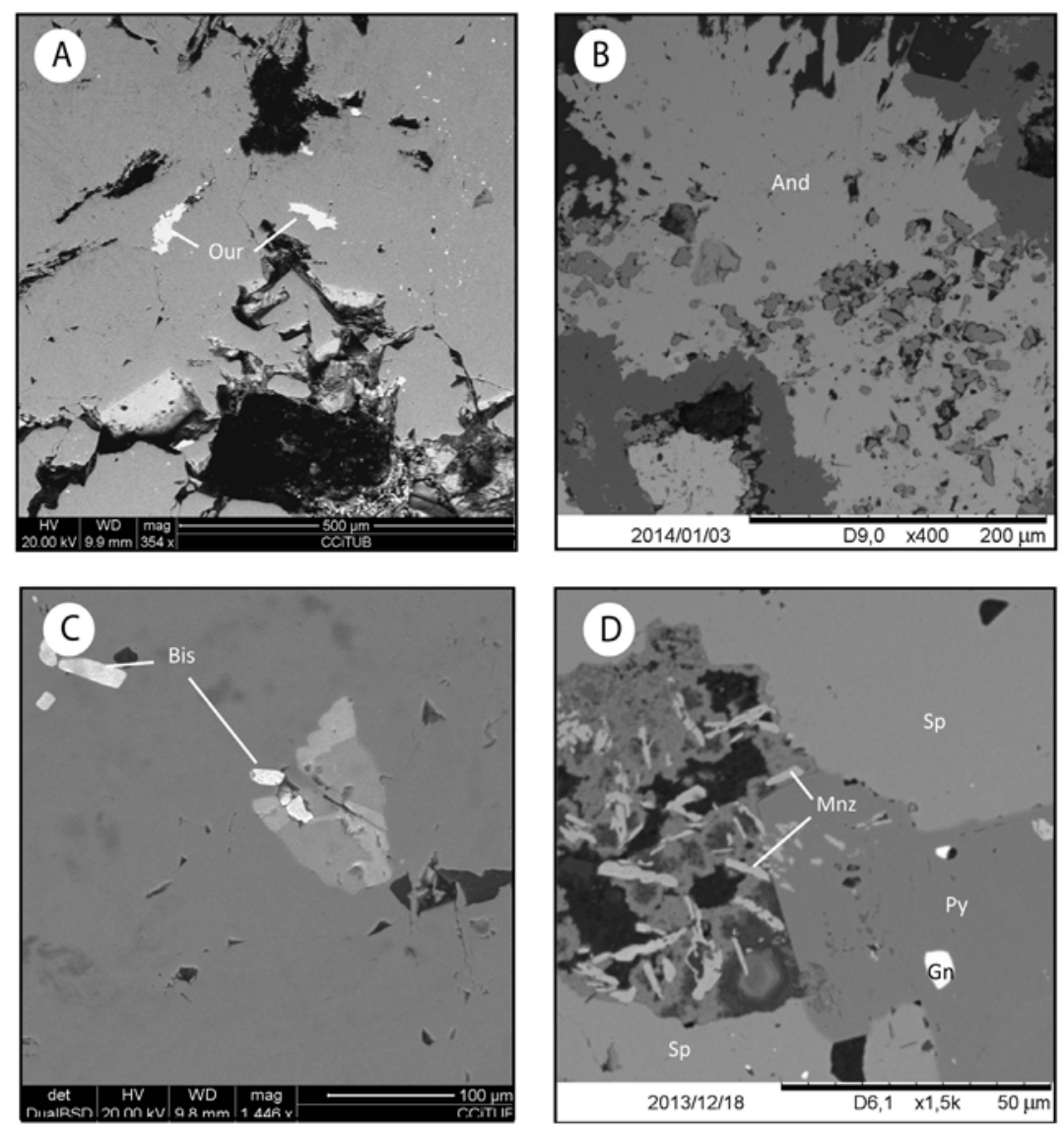

FIG. 9. Backscattered SEM images of: A. Ourayite filling cavities in a pyrite crystal; B. Acicular crystals of andorite; C. Bismuthinite crystals in a galena crystal; D. Acicular monazite crystals associated to sulfides. And: andorite; Bis: bismuthinite; Gn: galena; Our: ourayite; Py: pyrite; Sp: sphalerite; Mnz: monazite.

The genesis of a greisen deposit includes an early alkaline stage, a greisen stage itself and a late veining stage. Silicification is common in greisen alteration, evidenced by the common quartz flooding of the greisen altered rocks (Shcherba, 1970).

Moreover, increasing amounts of topaz (not found in the SFD), tourmaline and quartz in sericitic altered rocks herald a transition to greisen-type alteration; hydro-muscovite and illite can also be present. This alteration is due to the destabilization of feldspars in the presence of $\mathrm{H}^{+}, \mathrm{OH}^{-}, \mathrm{K}$ and $\mathrm{S}$, to form quartz, white mica, pyrite and chalcopyrite; sulfide content can be up to 20 volume \% (Fleet, 2003).

In the Santa Fe mining district evidence of postmagmatic hydrothermal activity was observed as an overprint mineral association of cassiterite \pm sphalerite, vermiculite, quartz, oligoclase, monazite, recording a metasomatic event, followed by progressive stages of F-and/or B-metasomatism; this is represented by the development of a quartz-tourmaline assemblage (Table 6).

Although the greisen alteration is common in continental porphyry systems, the most favorable environment is a granitic body emplaced within a meta-sedimentary sequence, and associated with Sn-W mineralization (Hall, 1971; Groves and McCarthy, 1978; Lehmann, 1981, 1982).

The destabilization and destruction of feldspar and biotite in the San Pablo stock to form the assemblage of quartz+muscovite result in a series of reactions that may take place to form the greisen alteration represented by topaz (not observed in the San Pablo stock), tourmaline, and oxide minerals (Table 6). In the Santa Fe mining district, during the greisen stage, the 
TABLE 6. ALTERATION MINERAL ASSEMBLAGES RECOGNIZED IN SELECTED SAMPLES FROM THE SANTA FE MINING DISTRICT.

\begin{tabular}{|c|c|c|c|}
\hline \# & Clave & Mineral assemblage & Alteration \\
\hline 1 & $\mathrm{~J}-2 \mathrm{~b}$ & $\begin{array}{l}\text { Quartz, illite-montmorillonite, } \\
\text { kaolinite, alunite, pyrite }\end{array}$ & Advanced argillic \\
\hline 2 & $\mathrm{~J}-2 \mathrm{c}$ & Quartz, kaolinite, rhomboclase, illite, anhydrite & Potassic \\
\hline 3 & $\mathrm{~J}-2 \mathrm{e}$ & $\begin{array}{l}\text { Quartz, rhomboclase, cassiterite, kaolinite, gypsum, alunite, montmorillonite, } \\
\text { vermiculite }\end{array}$ & Advanced argillic \\
\hline 5 & $\mathrm{~J}-3 \mathrm{~d}$ & Quartz, kaolinite, rhomboclase, sericite, biotite & Argillic \\
\hline 6 & $\mathrm{~J}-4$ & Quartz, vermiculite, sericite, illite, jarosite, monazite, gypsum & Greisen \\
\hline 7 & $\mathrm{~J}-7 \mathrm{a}$ & Quartz, vermiculite, sericite, illite, jarosite, monazite, gypsum & Greisen \\
\hline 8 & $\mathrm{~J}-7 \mathrm{~b}$ & Cassiterite, vermiculite, quartz, oligoclase, monazite & Greisen \\
\hline 9 & ASF-01 & Quartz, monazite, kaolinite, illite, sericite & Argillic \\
\hline 10 & ASF-02 & Hematite, cassiterite, quartz, sericite, illite, jarosite & Greisen \\
\hline 11 & ASF-03 & Sulfur, sericite, hematite, rhomboclase & Argillic \\
\hline 12 & ASF-04 & Orthoclase, anhydrite, sericite, chlorite, plumbojarosite & Potassic \\
\hline 13 & ASF-05 & Biotite, rhomboclase, illite, anhydrite, kaolinite & Potassic \\
\hline 15 & MCC-13 & Quartz, sphalerite, cassiterite, pyrite, kaolinite & Greisen \\
\hline 16 & MCC-17 & Goethite, melanterite, dickite, alunite, quartz, cassiterite & Advanced argillic \\
\hline 17 & MCC-18 & Pyrite, quartz, dickite, jarosite & Advanced argillic \\
\hline
\end{tabular}

Samples 1 to 8 from Japo mine, 9 to 13 from Santa Fe mine and 15 to 17 from Morococala.

mineralizing event was more extent than the magmatic due the interaction between the metasedimentary rocks and metal-rich hydrothermal fluids. This event has presented several episodes of metal deposition as an assemblage of cassiterite, pyrite, arsenopyrite, pyrrhotite, chalcocite and chalcopyrite.

Grant et al. (1979) and Sugaki et al. (2003) obtained geochronological data from the San Pablo stock ( $23 \mathrm{Ma}$ ) $)$ and mineralization $(\sim 20 \mathrm{Ma})$. In consequence, it is pointed out that the timing of tin-polymetallic mineralizations in the SFD is limited at two specific ages. The post magmatic event was temporary the longest for mineralization; after metasomatic stage, several episodes of metal deposition occurred forming veins or filling discontinuities, as lithological contacts or shear zones. Veins are infilled by an association of galena, argentite, sphalerite, stibnite, marcasite, stannite and sulfosalts. Finally, a later stage of supergene alteration, represented by sulfates as plumbogummite, melanterite and vivianite, took place.

\subsection{Indium mineralization in the Santa Fe Mining District}

The source of Sn and In is in continuous discussion and it is poorly assessable. Crustal materials that contain pre-existing metal concentrations can be a rich source of metals during episodes of partial melting. In this respect, there are limited data on the partitioning of metals, such as In, Sn and W, within major silicate minerals (Miroshnichenko, 1965; Alderton and Moore, 1981; Neiva et al., 2002). In addition, Simons et al. (2017) conducted a study about fractioning and distribution of litophile elements as $\mathrm{Li}, \mathrm{Be}, \mathrm{Ga}, \mathrm{Nb}, \mathrm{Ta}, \mathrm{In}, \mathrm{Sn}, \mathrm{Sb}, \mathrm{W}$ and $\mathrm{Bi}$. They pointed out that metals partition in muscovite represents sources of $\mathrm{Sn}$, where $\mathrm{P}$ and $\mathrm{F}$ cause the retention in the melt of $\mathrm{Nb}, \mathrm{Ta}, \mathrm{Sn}, \mathrm{W}$ and, to a lesser extent, In. However, a few studies have been done on indium crustal distribution (Taylor and McLennan, 1985; Rudnick and Gao, 2014; Werner et al., 2017). 


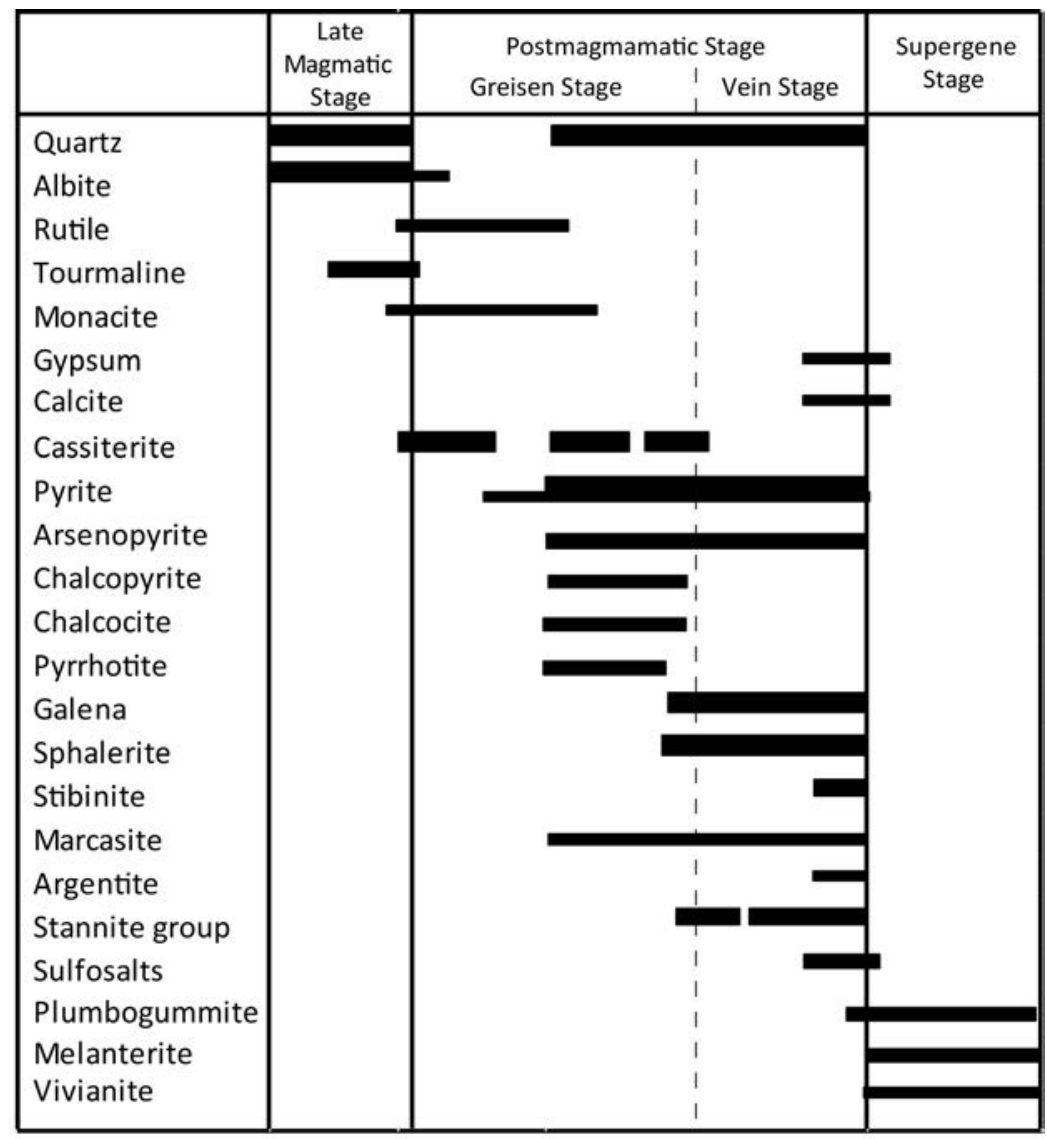

FIG. 10. Paragenetic sequence of the Santa Fe District.

Werner et al. (2017) propose an indium average of $0.0556 \mathrm{ppm}$ in the crust, based on the correlation between Sn and In concentrations in the deposits reported in the current literature. Only few Inrich minerals are known in nature (e.g., Taylor and McLennan, 1985; Schwarz-Schampera and Herzig, 2002; Cook et al., 2011b): Indite $\left(\mathrm{FeIn}_{2} \mathrm{~S}_{4}\right)$, cadmoindite $\left(\mathrm{CdIn}_{2} \mathrm{~S}_{4}\right)$, roquesite $\left(\mathrm{CuInS}_{2}\right)$, laforêtite $\left(\mathrm{AgInS}_{2}\right)$, sakuraiite $\left[(\mathrm{Cu}, \mathrm{Zn}, \mathrm{Fe})_{3}(\mathrm{In}, \mathrm{Sn}) \mathrm{S}_{4}\right]$ petrukite $\left[(\mathrm{Cu}, \mathrm{Fe}, \mathrm{Zn})_{2}(\mathrm{Sn}, \mathrm{In}) \mathrm{S}_{4}\right]$, damiaoite $\left(\mathrm{PtIn}_{2}\right)$ and yixunite $\left(\mathrm{Pt}_{3} \mathrm{In}\right)$. Native indium was first found on 1963 in a tin-bearing greisen deposit of the Ukrainian Shield. According to Seifert and Sandmann (2006), polymetallic and base metal vein deposits as well as granite-related tin-base metal deposits (vein and greisen-type orebodies) are among the most important hosts for In-bearing mineralization, e.g., a granite related In-bearing occurrence has been reported in Finland (Cook et al., 2011b; Valkama et al., 2016).
Although the vast majority of indium is obtained from sphalerite, where it occurs by ionic substitution of Zn (Cook et al., 2011a; Cook et al., 2011b), a strong link between Sn and In was also suggested. Yi et al. (1995) reported that $\mathrm{In} / \mathrm{Sn}$ ratio varies from $<0.1$ to 47 in sulfides and Qian et al. (1998) found that indium occurs when $\mathrm{Pb}-\mathrm{Zn}$ deposits are $\mathrm{Sn}$ rich. Likewise, Serranti et al. (2002) reported up to $394 \mathrm{ppm}$ of indium in cassiterite from the NevesCorvo deposit, Portugal. Benzaazoua et al. (2003), after an accurate study using multiple regression coefficients, determined a strong enrichment of indium in stannite group minerals. Recently, Pavlova et al. (2015) reported an extend study of indium content in several deposits of Russia, Vietnam and Germany, in cassiterite and other tin minerals. They reported until $485 \mathrm{ppm}$ of In in cassiterite, 100-25,000 ppm in sphalerite and up to $1,000 \mathrm{ppm}$ in chalcopyrite, and, in the case of stannite, up to $60,000 \mathrm{ppm}$. 
In comparison, in the SFD indium occurs mostly in stannite group, as phases belonging to a complex stannite, sakuraiite and kësterite solid solution and other phases of the S-Sn-Cu-Zn-Fe system. Few analyses from cassiterite reported up to $0.25 \mathrm{wt} \%$ In, however most of them show lower contents. Sphalerite is also depleted in In.

Stannite group has several members; some of them are currently cause of controversy. As mentioned above, stannite is conventionally used for $\mathrm{Fe}>\mathrm{Zn}$ phases, and kësterite for $\mathrm{Zn}>\mathrm{Fe}$, accepting substitutions of $[(\mathrm{Zn}, \mathrm{Fe}) \mathrm{In}]$ for $\mathrm{Cu}-\mathrm{Sn}$. However, the most common substitution of $\mathrm{Sn}$ for In is seen in sakuraiite (Shimizu et al., 1986). Figure 11A illustrates these compositional variations of stannite group and their relationship with sulfosalts. Sakuraiite analysis can be interpreted as solid solutions along the stannite and kësterite continuous compositional series. The SEM-EDS and microprobe results in this study show that sakuraiite is formed as tetrahedral crystals with a general structural formula as $\left[(\mathrm{Cu}, \mathrm{Zn}, \mathrm{Fe})_{3}(\mathrm{Sn}, \mathrm{In},) \mathrm{S}_{4}\right]$, which is consistent to Shimizu et al. (1986). Sakuraiite has up to $2.03 \mathrm{wt} \%$ of In (Figs. 8F, 11B; Tables 4, 5).

In-bearing or deposits have been reported from localities world-wide (Ohta, 1989; Murao and Furuno,
1991; Seifert and Sandmann, 2006; Sinclair et al., 2006; Murao et al., 2008; Ishihara et al., 2011; Cook et al., 2011b; Murakami and Ishihara, 2013; Dill et al., 2013; Valkama et al., 2016); a summary of results of In contents reported by these authors is shown in figure 12. Ishihara et al. (2006) reported in different Japanese ore deposits that indium displays high correlation with $\mathrm{Sn}$ and $\mathrm{Ga}$, and lowest with $\mathrm{Zn}$. In the South American context, like Argentinian deposits of San Roque and Pingüinos, for example indium is strongly related to $\mathrm{Sn}$. In the San Roque deposit 5,437 ppm of In was reported (Ishihara et al., 2011), whereas that in the Pingüinos deposit, Jovic et al. (2011) reported up to $1,184 \mathrm{ppm}$. On the other hand, in the Bolivian deposits Ishihara et al. (2011) reported up to 3,080 ppm in the Huari Huari deposit; the maximum $1,000 \times \mathrm{In} / \mathrm{Zn}$ ratios in this country are of 22.19 (Potosí), 11.2 (Huari Huari) and 7.42 (Bolivar) (Murakami and Ishihara, 2013). Murakami and Ishihara (2013) also reported the estimated indium production in major Sn-polymetallic deposits in Bolivia and the corresponding inferred tonnage. The Bolivar deposit has 1,092 indium tons and an inferred tonnage of 45.0 MT with average of 600 ppm Sn, 156 ppm Ag and 57.8\% Zn; Colquiri has

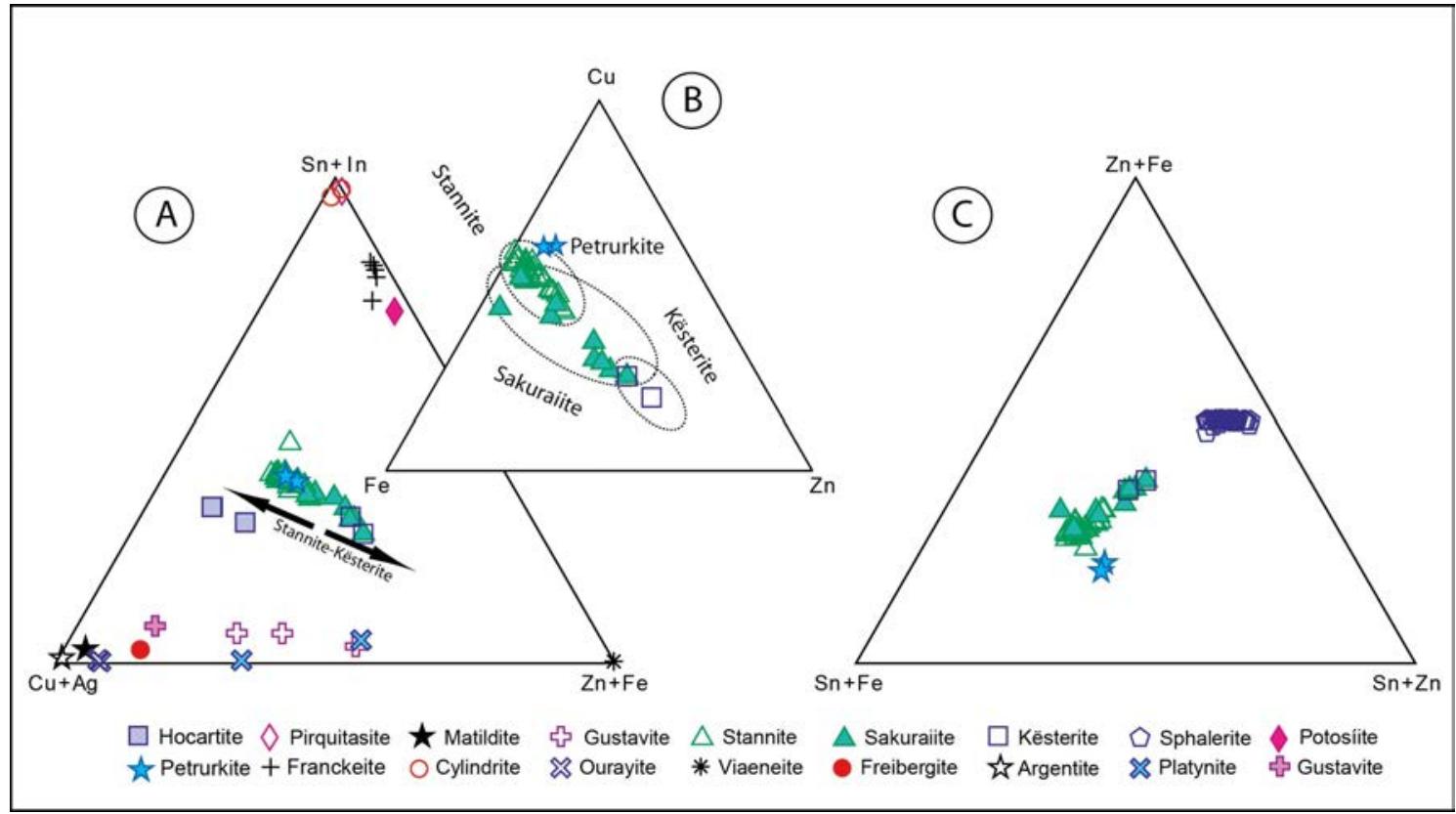

FIG. 11. A. Ternary $\mathrm{Cu}+\mathrm{Ag}-\mathrm{Sn}+\mathrm{In}-\mathrm{Zn}+\mathrm{Fe}$ plot of indium-rich minerals from the SFD; B. Ternary diagram Fe-Cu-Zn, plot compositional difference between Stannite-Sakuraiite-Petrurkite-Kësterite-Sphalerite phases; $\mathbf{C}$. $\mathrm{Sn}+\mathrm{Fe}-\mathrm{Zn}+\mathrm{Fe}-\mathrm{Sn}+\mathrm{Zn}$. 


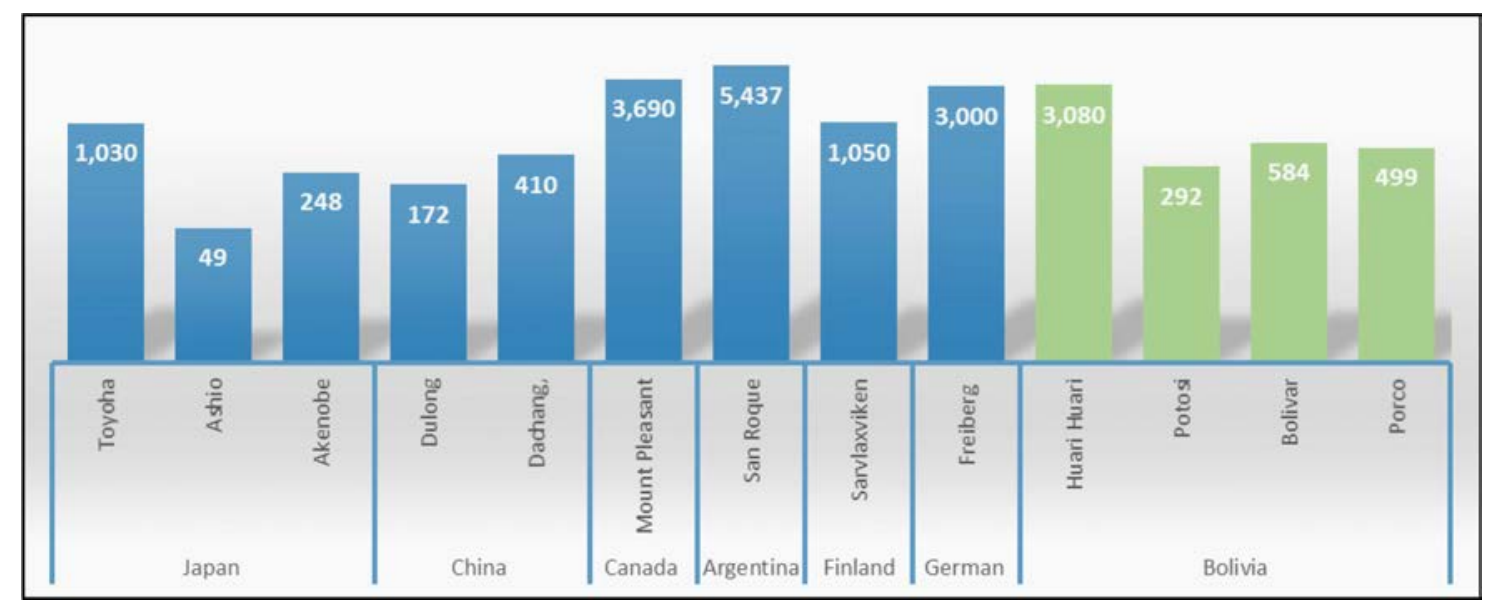

FIG. 12. Indium content of selected In-bearing deposits in ppm. Ore concentrates for Canadian, finnish, german and argentinian deposits, Zn concentrates for japanesse, Chinese and bolivian deposits (Valkama et al., 2016; Murakami and Ishihara, 2013; Dill et al., 2013; Ishihara et al., 2011; Cook et al., 2011b; Sinclair et al., 2006; Murao and Furuno, 1991; Murao et al., 2008, Ohta, 1989; Seifert and Sandmann, 2006).

484 tons of In and an inferred tonnage of 2.0 MT; Porco has 997 tons of In and an inferred tonnage of $3.7 \mathrm{MT}$ with average of $618 \mathrm{ppm} \mathrm{Sn}, 36 \mathrm{ppm} \mathrm{Ag}$ and 55.1\% Zn; and Potosí has 4,037 tons of In and an inferred tonnage of 541.0 MT with average of 6,780 ppm Sn, $223 \mathrm{ppm} \mathrm{Ag} \mathrm{and} \mathrm{60.4 \%} \mathrm{Zn.} \mathrm{Finally,}$ a total of 1,106.7 MT of inferred resources of indium in Bolivia were estimated with data provided by Arce-Burgoa and Goldfarb (2009). In comparison, in the SFD the In content reach up to $54.5 \mathrm{ppm}$ and the $1,000 \times \operatorname{In} / \mathrm{Zn}$ ratio vary from 26 up to 1,298 in the ore (Table 1).

Furthermore, higher grades of In are associated with high grades of Sn, suggesting that this correlation may be used to predict the grade of indium where $\mathrm{Sn}$ grades are reported. However, indium grades can be highly variable within particular mineral hosts, and a greater number of reported deposits do not reduce statistical uncertainty. In addition, in order to the mineralogical information be reliable, would be necessary to link it to other geological factors that would be more likely known about a deposit (Werner et al., 2017).

\section{Concluding remarks}

According to results from the SFD, indium is mostly found in Sn minerals; it was also found in high amounts in ore concentrate (200 ppm), where Sn content is more than $1,000 \mathrm{ppm}$. Thus, the significant potential of obtaining Sn and In in the SFD from the ore concentrate itself is a key target.

The mineral assemblage of the SFD is consistent with a greisen ore system. In the Santa Fe deposit, three main paragenetic stages can be inferred, from former to latter: (1) Magmatic stage and injection of hydrothermal fluids rich in metals, especially in Sn (resulting in cassiterite precipitation); (2) metasomatism, producing the alteration of metasedimentary sequence as a greisen stage and vein formation with sulfides deposition (In-bearing minerals, mostly stannite); and (3) supergene alteration that formed a replacive paragenesis rich in phosphates.

The SFD is known by the tin mineralization; however, an important number of metal associations, including base, alloy, noble and critical metals, have been found in this ore deposit. The most important ore associations from the point of view of their economic interest are: (1) tin mineralization, and (2) indium-bearing sulfides.

Japo and Morococala deposits have exceptional In values, which occur in sakuraiite. Sakuraiite found in this deposit shows evidences for a link between stannite and kësterite trend of solid solutions, the highest indium content is $2.03 \mathrm{wt} \%$; however, the analysis of In-tin minerals by EPMA is problematic due to intense line interference of InL $\alpha$ and SnL $\eta$. A specific study about the indium distribution and structure solution to atomic scale of sakuraiite will be the key to resolve this issue. 
There is an obvious exploration potential for strategic metals in this deposit and even in similar deposits also elsewhere in the Central Andean Tin Belt.

\section{Acknowledgements}

This work was partly financed by the project AECID: A3/042750/11, the Centre de Cooperació per al Desenvolupament of the UPC (CCD 2013UO010, 2014U002) and the SGR 2014 SGR 1661. A. Jiménez is supported with a grant from the Mexican Secretariat of Education (SEP) and the National Council on Science and Technology (CONACYT) of Mexico. The authors acknowledge to Andean Geology referees for their constructive comments on the manuscript. We also gratefully acknowledge to Maite Garcia-Valles of the Universitat de Barcelona for her important contributions on different aspects of this work. The authors would like to thank the staff of the Japo, Santa Fe and Morococala mines for their kind guidance. The EPMA analyses were obtained at the Serveis Cientícs i Tecnològics de la Universitat de Barcelona (CCiT-UB) and Laboratorio Universitario de Petrología, of the Instituto de Geofísica, UNAM. We thank Xavier Llovet and Carlos Linares López for them assistance during the EPMA analyses.

\section{References}

ActLab Ltd. 2017. 4Lithores-Lithium Metaborate/ Tetraborate Fusion-ICP and ICP/MS (online) Available: http:/www.actlabs.com/page.aspx?page=517\&app= $226 \&$ cat $1=549 \& \mathrm{tp}=12 \& 1 \mathrm{k}=$ no\&menu $=64$ (last visit 06-08-2018).

Ahlfeld, F. 1926. Zinkteallite und alaskaite aus Bolivia. (Zincteallite and alaskaite from Bolivia). Centralblatt für Mineralogie, Geologie und Paläontologie 12: 388-390.

Ahlfeld, F. 1967. Metallogenetic epochs and provinces of Bolivia. Mineralium Deposita 2: 291-311.

Ahfeld, F.; Schneider-Scherbina, A. 1964. Los yacimientos minerales y de hidrocarburos de Bolivia. Ministerio de minas y petróleo. Departamento Nacional de Geología del Ministerio de Minas y Petróleo, Publicación Especial, Boletín 5: 388 p. La Paz.

Alderton, D.H.M.; Moore, F. 1981. New determinations of tin and tungsten in granites from south-west England. Mineralogical Magazine 44 (335): 354-356.

Arce-Burgoa, O.R.; Goldfarb, R.J. 2009. Metallogeny of Bolivia. Society of Economic Geologists Newsletter 79 (4-4): 1-15.

Benzaazoua, M.; Marion, P.; Pinto, A.; Migeon, H.; Wagner, F.E. 2003. Tin and indium mineralogy within selected samples from the Neves Corvo ore deposit (Portugal): a multidisciplinary study. Mineral Engineering 16 (11-12): 1291-1302.

Burt, D. 1981. Acidity-salinity diagrams-Application to greisenand porphyry deposits. Economic Geology 76 (4-8): 832-843.

Chapman, A.; Arendorf, J.; Castella, T.; Thompson, P.; Willis, P.; Tercero-Espinoza, L.; Klug, S.; Wichmann, E. 2013. Study on Critical Raw Materials at EU Level. Final Report. Oakdene Hollins and Fraunhofer ISI: $166 \mathrm{p}$.

Cook, N.J.; Ciobanu, C.L.; Wagner, T.; Stanley, C.J. 2007. Minerals of the system Bi-Te-Se-S related to the tetradymite archetype: review of classification and compositional variation. The Canadian Mineralogist 45 (4-6): 665-708.

Cook, N.J.; Ciobanu, C.L.; Williams, T. 2011a. The mineralogy and mineral chemistry of indium in sulphide deposits and implications for mineral processing. Hydrometallurgy 108 (3-4): 226-228.

Cook, N.J.; Sundblad, K.; Valkama, M.; Nygård, R.; Ciobanu, C.L.; Danyushevsky, L. 2011b. Indium mineralisation in A-type granites in southeastern Finland: Insights into mineralogy and partitioning between coexisting minerals. Chemical Geology 284 (1-2): 62-73.

Dill, H.G.; Garrido, M.M.; Melcher, F.; Gómez, M.C.; Weber, B.; Luna, L.I.; Bahr, A. 2013. Sulfidic and non-sulfidic indium mineralization of the epithermal $\mathrm{Au}-\mathrm{Cu}-\mathrm{Zn}-\mathrm{Pb}-\mathrm{Ag}$ deposit San Roque (Provincia Río Negro, SE Argentina)-with special reference to the "indium window" in zinc sulfide. Ore Geology Reviews 51: 103-128.

Effenberger, H.; Paar, W.H.; Topa, D.; Criddle, A.J.; Fleck, M. 2002. The new mineral baumstarkite and a structural reinvestigation of aramayoite and miargyrite. American Mineralogist 87 (5-6): 753-764.

Evernden, J.F.; Kriz, S.J.; Cherroni, C. 1977. Potassium argon ages of some Bolivian rocks. Economic Geology 72 (6-8): 1042-1061.

Fleet, M.E. 2003. Sheet silicates: Micas. In Rock-forming minerals (Deer, W.A.; Howie, R.A.; Wise, W.S.; Zussman, J.; editors). The Geological Society of London 3A: 758 p. London. doi: 10.1180./0680831

Fleischer, M. 1969. New mineral names. American Mineralogist 54: 326-330.

Fleischer, M.; Chao, G.Y.; Kato, I. 1975. New mineral names. American Mineralogist 60: 485-489.

Frondel, C. 1943. Mineralogy of the oxides and carbonates of bismuth. American Mineralogist 28: 521-535. 
Grant, J.N.; Halls, C.; Ávila-Salinas, W.; Snelling, N.J. 1979. K-Ar ages of igneous rocks and mineralization in part of the Bolivian tin belt. Economic Geology 74 (4-8): 838-851.

Groves, D.I.; McCarthy, T.S. 1978. Fractional crystallization and the origin of tin deposits in granitoids. Mineralium Deposita 13 (1-3): 11-26.

Hall, A. 1971. Greisenisation in the granite of Cligga Head, Cornwall. Proceedings of the Geologists' Association 82 (2-4): 209-230.

Hall, S.R.; Szymanski, J.T.; Stewart, J.M. 1978. Kesterite, $\mathrm{Cu}_{2}(\mathrm{Zn}, \mathrm{Fe}) \mathrm{SnS}_{4}$, and stannite, $\mathrm{Cu}_{2}(\mathrm{Fe}, \mathrm{Zn}) \mathrm{SnS}_{4}$, structurally similar but distinct minerals. The Canadian Mineralogist 16 (2-4): 131-137.

Ishihara, S.; Hoshino, K.; Murakami, H.; Endo, Y. 2006. Resource evaluation and some genetic aspects of indium in the Japanese ore deposits. Resource Geology 56 (3-4): 347-364.

Ishihara, S.; Murakami, H.; Márquez-Zavalia, M.F. 2011. Inferred Indium Resources of the Bolivian Tin-Polymetallic Deposits. Resource Geology 61 (2-4): 174-191.

Johan, Z.; Picot, P. 1982. La pirquitasite, Ag2ZnSnS4, un nouveau membre du groupe de la stannite. Bulletin de Minéralogie (105): 229-235.

Johnson, N.E.; Craig, J.R.; Rimstidt, J.D. 1988. Crystal chemistry of tetrahedrite. American Mineralogist 73 (3-4): 389-397.

Jovic, S.M.; Guido, D.M.; Ruiz, R.; Páez, G.N.; Schalamuk, I.B. 2011. Indium distribution and correlations in polymetallic veins from Pingüino deposit, Deseado Massif, Patagonia, Argentina. Geochemistry: Exploration, Environment, Analysis 11 (2-4): 107-115.

Kelly, W.C.; Turneaure, F.S. 1970. Mineralogy, paragenesis and geothermometry of the tin and tungsten deposits of the eastern Andes, Bolivia. Economic Geology 65 (5-8): 609-680.

Kharbish, S.; Jeleň, S. 2016. Raman spectroscopy of the $\mathrm{Pb}-\mathrm{Sb}$ sulfosalts minerals: Boulangerite, jamesonite, robinsonite and zinkenite. Vibrational Spectroscopy 85: 157-166.

Kissin, S.A.; Owens, D.A. 1986. The crystallography of sakuraiite. The Canadian Mineralogist 24 (4-4): 679-683.

Kucha, H.; Osuch, W.; Elsen, J. 1996. Viaeneite (Fe, Pb) ${ }_{4} \mathrm{~S}_{8} \mathrm{O}$, A new mineral with mixed sulphur valencies from Engis, Belgium. European Journal of Mineralogy 8 (1-5): 93-102.

Kuze, S.; Du Boulay, D.; Ishizawa, N.; Saiki, A.; Pring, A. 2004. X-ray diffraction evidence for a monoclinic form of stibnite, $\mathrm{Sb}_{2} \mathrm{~S}_{3}$, below $290 \mathrm{~K}$. American Mineralogist 89 (7-12): 1022-1025.

Lavenu, A.; Bonhomme, M.G.; Vatin-Perignon, N.; De Pachtere, P. 1985. Neogene magmatism in the Bolivian Andes (between $16^{\circ}$ and $18^{\circ} \mathrm{S}$ ). Part 1: Numerical stratigraphy (K-Ar) and tectonics. Universidad de Chile, Departamento de Geología, Comunicaciones 35: 121-124.

Lehmann, B. 1981. A discussion of the paper by M. Boissavy-Vinau and G. Roger "the TiO 2/Ta ratio as an indicator of the degree of differentiation of tin granites". Mineralium Deposita 16 (2-3): 329-331.

Lehmann, B. 1982. Metallogeny of tin; magmatic differentiation versus geochemical heritage. Economic Geology 77 (1-8): 50-59.

Lehmann, B.; Ishihara, S.; Michel, H.; Miller, J.; Rapela, C.W.; Sánchez, A.; Tistl, M.; Winkelmann, L. 1990. The Bolivian tin province and regional tin distribution in the Central Andes; a reassessment. Economic Geology 85 (5-8): 1044-1058.

Makovicky, E.; Karup-Møller, S. 1977. Chemistry and crystallography of the lillianite homologous series II. Definition of new minerals eskimoite, vikingite, ourayite and treasurite. Redefinition of schirmerite and new data on the lillianite-gustavite solid-solution series. Neues Jahrbuch für Mineralogie, Abhandlungen 131: 56-82.

Miroshnichenko, L.A. 1965. New data on distribution of indium in ore deposits of Central Kazakhstan. International Geology Review 7 (2-12): 233-240.

Mlynarczyk, M.; William-Jones, A. 2005. The role of collisional tectonics in the metallogeny of the Central Andean tin belt. Earth and Planetary Science Letters 240 (3-4): 656-667.

Moh, G.H.; Berndt, F. 1964. Two new natural tin sulfides, $\mathrm{Sn}_{2} \mathrm{~S}_{3}$ and $\mathrm{SnS}_{2}$. Neues Jahrbuch für Mineralogie, Abhandlungen 3: 94-95.

Morgan, G.B.; London, D.; Luedke, R.G. 1998. Petrochemistry of late Miocene peraluminous silicic volcanic rocks from the Morococala field, Bolivia. Journal of Petrology 39 (4-12): 601-632.

Murakami, H.; Ishihara, S. 2013. Trace elements of Indiumbearing sphalerite from tin-polymetallic deposits in Bolivia, China and Japan: A femto-second LA-ICPMS study. Ore Geology Reviews 53: 223-243.

Murao, S.; Furuno, M. 1991. Roquesite from the Akenobe tin-polymetallic deposits, Southwest Japan. Bulletin of the Geological Survey of Japan 42 (1-12): 1-10.

Murao, S.; Deb, M.; Furuno, M. 2008. Mineralogical evolution of indium in high grade tin-polymetallic 
hydrothermal veins-a comparative study from Tosham, Haryana state, India and Goka, Naegi district, Japan. Ore Geology Reviews 33 (3-4): 490-504.

Neiva, A.M.R.; Silva, M.M.V.G.; Gomes, M.E.P.; Campos, T.F.C. 2002. Geochemistry of coexisting biotite and muscovite of Portuguese peraluminous granitic differentiation series. Chemie der Erde-Geochemistry 62 (3-4): 197-215.

Ohta, E. 1989. Occurrence and chemistry of indiumcontaining minerals from the Toyoha mine, Hokkaido, Japan. Mining Geology 39: 355-372.

Pavlova, G.G.; Palessky, S.V.; Borisenko, A.S.; Vladimirov, A.G.; Seifert, T.; Phan, L.A. 2015. Indium in cassiterite and ores of tin deposits. Ore Geology Reviews 66: 99-113.

Petruk, W. 1973. Tin sulphides from the deposit of Brunswick Tin Mines Limited. The Canadian Mineralogist 12 (1-7): 46-54.

Petruk, W.; Owens, D.R.; Stewart, J.M.; Murray, E.J. 1974. Observations on acanthite, aguilarite and naumannite. The Canadian Mineralogist 12 (6-7): 365-369.

Pirajno, F. 2009. Hydrothermal Processes and Mineral Systems. Springer: 1250 p. Netherlands.

Qian, Z.; Xinzhi, Z.; Jiayong, P.; Shuxun, S. 1998. Geochemical enrichment and mineralization of indium. Acta Geochimica 17 (3-4): 221-225.

Rudnick, R.L.; Gao, S. 2014. Composition of the continental crust. In Treatise on Geochemistry (Turekian, H.D.; Holland, K.K.; editors). Second edition Elsevier: 1-64. Oxford.

Schwarz-Schampera, U.; Herzig, P.M. 2002. Indium: Geology, Mineralogy and Economics. Springer-Verlag: 262 p. Heidelberg.

Seal, R.R.; Essene, E.J.; Kelly, W.C. 1990. Tetrahedrite and tennantite: evaluation of thermodynamic data and phase equilibria. The Canadian Mineralogist 28 (4-4): 725-738.

Seifert, T.; Sandmann, D. 2006. Mineralogy and geochemistry of indium-bearing polymetallic veintype deposits: Implications for host minerals from the Freiberg district, Eastern Erzgebirge, Germany. Ore Geology Reviews 28 (1-4): 1-31.

Serranti, S.; Ferrini, V.; Masi, U.; Cabri, L.J. 2002. Trace-element distribution in cassiterite and sulfides from Rubané and massive ores of the Corvo deposit, Portugal. The Canadian Mineralogist 40 (3-6): 815-835.

Shcherba, G.N. 1970. Greisens. International Geology Review 12 (2-2): 114-150.

Shimizu, M.; Kato, A.; Shiozawa, T. 1986. Sakuraiite: chemical composition and extent of $(\mathrm{Zn}, \mathrm{Fe}) \mathrm{In}-\mathrm{CuSn}$ substitution. The Canadian Mineralogist 24 (2-4): 405-409.

Shimizu, M.; Kato, A.; Matsuyama, F. 1998. Two Sebearing Ag-Bi sulphosalts, benjaminite and matildite from the Ikuno Deposits, Hyogo Prefecture, Japan -Au-Ag mineralization in polymetallic Zone. Resource Geology 48 (2-4) 117-124.

Sillitoe, R.H.; Halls, C.; Grant, J.N. 1975. Porphyry tin deposits in Bolivia. Economic Geology 70 (5-8): 913-927.

Simons, B.; Andersen, J.C.Ø.; Shail, R.K.; Jenner, F. 2017. Fractionation of $\mathrm{Li}, \mathrm{Be}, \mathrm{Ga}, \mathrm{Nb}, \mathrm{Ta}, \mathrm{In}, \mathrm{Sn}$, $\mathrm{Sb}, \mathrm{W}$ and $\mathrm{Bi}$ in the peraluminous Early Permian Variscan granites of the Cornubian Batholith: precursor processes to magmatic-hydrothermal mineralisation. Lithos 278-281: 491-512.

Sinclair, W.D.; Kooiman, G.; Martin, D.; Kjarsgaard, I.M. 2006. Geology, geochemistry and mineralogy of indium resources at Mount Pleasant, NewBrunswick, Canada. Ore Geology Reviews 28 (1-3): 123-145.

Sugaki, A.; Ueno, H.; Shimada, N.; Kitakaze, A.; Hayashi, K.; Shima, H.; Sanjines, O.V.; Saavedra, A.M. 1981. Geological study on poly metallic hydrothermal deposits in the Oruro District Bolivia. Science Reports of the Tohoku University III (XV-1): 1-52.

Sugaki, A.; Kitakaze, A.; Shima, H. 1982. Synthesis of cosalite and its phase relations in the $\mathrm{Cu}-\mathrm{Pb}-\mathrm{Bi}-\mathrm{S}$ quaternary system. In Crystal Chemistry of Minerals, Proceedings $13^{\text {th }}$ General Meeting of the International Mineralogical Association: 291-298. Varna.

Sugaki, A.; Kojima, S.; Shimada, N. 1988. Fluid inclusion studies of the polymetallic hydrothermal ore deposits in Bolivia. Mineralium Deposita 23 (1-4): 9-15.

Sugaki, A.; Shimada, N.; Ueno, H.; Kano, S. 2003. K-Ar Ages of Tin-Polymetallic Mineralization in the Oruro Mining District, Central Bolivian Tin Belt. Resource Geology 53: (4-4): 273-282.

Taylor, S.R.; McLennan, S.M. 1985. The continental crust: its composition and evolution. Springer: 312 p. Oxford.

Tolcin, A.C. 2016. Indium. In 2014 Minerals Yearbook. (Lee-Bray, E.; editor). United States Geological Survey: 35.1-35.7.

Topa, D.; Makovicky, E. 2010. The crystal chemistry of cosalite based on new electron-microprobe data and single-crystal determinations of the structure. The Canadian Mineralogist 48 (5-6): 1081-1107.

Turekian, K.K.; Wedepohl, K.H. 1961. Distribution of the elements in some major units of the earth's crust. Geological Society of America, Bulletin 72 (2-12): 175-192. 
Turneaure, F.S. 1960. A comparative study of major ore deposits of central Bolivia. Economic Geology 55 (2-8): 217-254.

Valkama, M.; Sundblad, K.; Nygård, R.; Cook, N. 2016. Mineralogy and geochemistry of indiumbearing polymetallic veins in the Sarvlaxviken area, Lovisa, Finland. Ore Geology Reviews 75: 206-219.

Werner, T.T.; Mudd, G.M.; Jowitt, S.M. 2017. The world's by-product and critical metal resources part II: A method for quantifying the resources of rarely reported metals. Ore Geology Reviews 80: 658-675.

Williams, T.B.; Hyde, B.G. 1988. Electron microscopy of cylindrite and franckeite. Physics and Chemistry of Minerals 15 (6-6): 521-544.

Yi,W.; Halliday, A.N.; Lee, D.-C.; Christensen, J.N. 1995. Indium and tin in basalts, sulfides, and the mantle. Geochimica et Cosmochimica Acta 59: 5081-5090.

Manuscript received: March 22, 2017; revised/accepted: January 11, 2018; available online: May 31, 2018. 